Chapter 3

\title{
Geologic Assessment of Undiscovered Oil and Gas Resources in the Phosphoria Total Petroleum System of the Wind River Basin Province, Wyoming
}

By M.A. Kirschbaum, P.G. Lillis, and L.N.R. Roberts

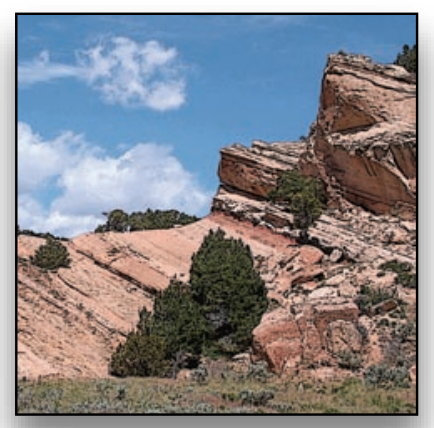

Click here to return to Volume Title Page

Chapter 3 of

Petroleum Systems and Geologic Assessment of Oil and Gas in the Wind River Basin Province, Wyoming

Compiled by USGS Wind River Basin Province Assessment Team

U.S. Geological Survey Digital Data Series DDS-69-J 


\section{U.S. Department of the Interior \\ DIRK KEMPTHORNE, Secretary}

\section{U.S. Geological Survey \\ Mark D. Myers, Director}

\section{U.S. Geological Survey, Reston, Virginia: 2007}

For product and ordering information:

World Wide Web: http://www.usgs.gov/pubprod

Telephone: 1-888-ASK-USGS

For more information on the USGS - the Federal source for science about the Earth, its natural and living resources,

natural hazards, and the environment:

World Wide Web: http://www.usgs.gov

Telephone:1-888-ASK-USGS

Any use of trade, product, or firm names is for descriptive purposes only and does not imply endorsement by the U.S. Government.

Although this report is in the public domain, permission must be secured from the individual copyright owners to

reproduce any copyrighted materials contained within this report.

Suggested citation:

Kirschbaum, M.A., Lillis, P.G., and Roberts, L.N.R., 2007, Geologic assessment of undiscovered oil and gas resources in the Phosphoria Total Petroleum System of the Wind River Basin Province, Wyoming, in USGS Wind River Basin Province assessment team, Petroleum systems and geologic assessment of oil and gas in the Wind River Basin Province, Wyoming: U.S. Geological Survey Digital Data Series DDS-69-J, ch. 3, 27 p. 


\section{Contents}

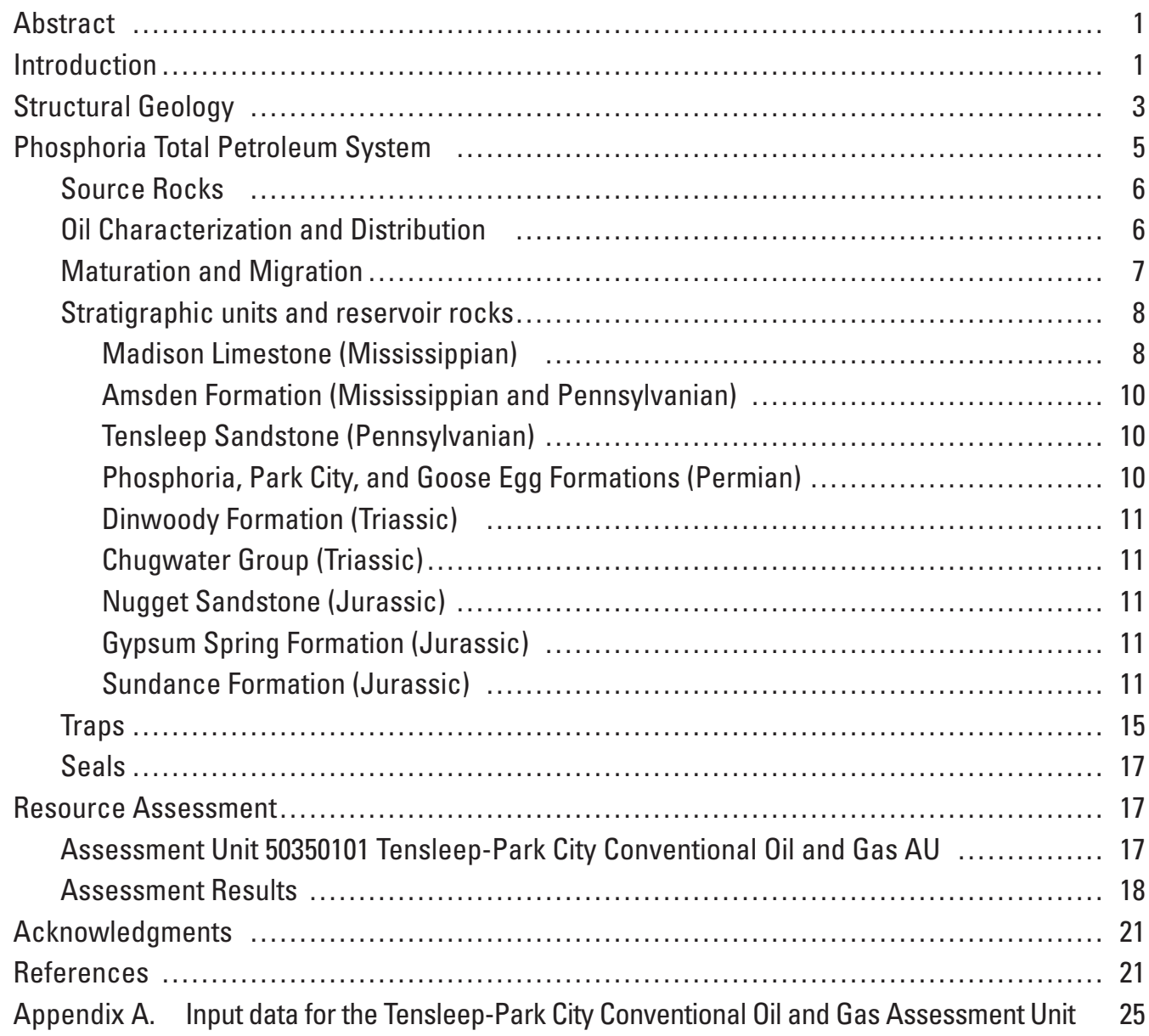

\section{Figures}

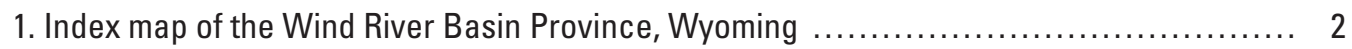

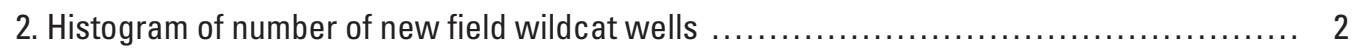

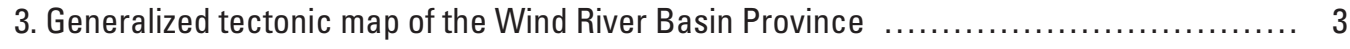

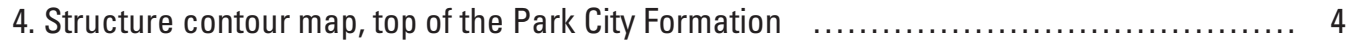

5. Petroleum system events chart Phosphoria Total Petroleum System ................... 5

6. Columnar section of units in the Phosphoria Total Petroleum System ................... 5

7. Organic carbon and black shale facies in the Phosphoria Formation $\ldots \ldots \ldots \ldots \ldots \ldots \ldots \ldots \ldots$

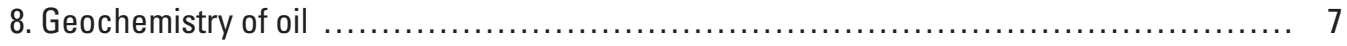

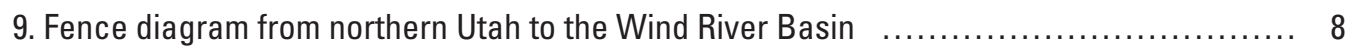


10. Timing of oil cracking to gas

9

11. Stratigraphic cross section western part of the Wind River Basin $\ldots \ldots \ldots \ldots \ldots \ldots \ldots .12,13$

12. Photographs of main reservoir units in the Wind River Basin Province .................. 15

13. Lithofacies and paleogeography of the Meade Peak Member ...................... 16

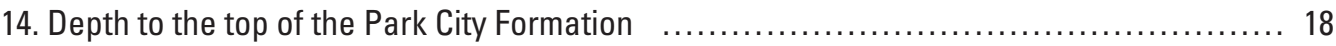

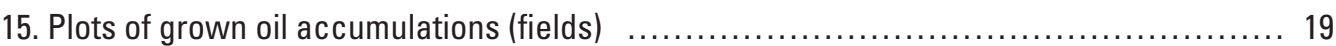

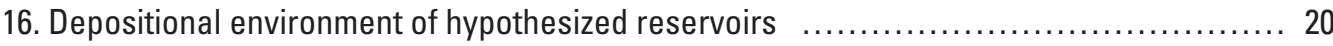

\section{Table}

1. Summary of assessment results for the Phosphoria Total Petroleum System

\section{Plate}

1. Stratigraphic cross section showing TPS units in Wind River Basin and Bighorn Basin ........ 27 


\title{
Geologic Assessment of Undiscovered Oil and Gas Resources in the Phosphoria Total Petroleum System of the Wind River Basin Province, Wyoming
}

\author{
By M.A. Kirschbaum, P.G. Lillis, and L.N.R. Roberts
}

\begin{abstract}
The Phosphoria Total Petroleum System (TPS) encompasses the entire Wind River Basin Province, an area of 4.7 million acres in central Wyoming. The source rocks most likely are black, organic-rich shales of the Meade Peak and Retort Phosphatic Shale Members of the Permian Phosphoria Formation located in the Wyoming and Idaho thrust belt to the west and southwest of the province. Petroleum was generated and expelled during Jurassic and Cretaceous time in westernmost Wyoming and is interpreted to have migrated into the province through carrier beds of the Pennsylvanian Tensleep Sandstone where it was preserved in hypothesized regional stratigraphic traps in the Tensleep and Permian Park City Formation. Secondary migration occurred during the development of structural traps associated with the Laramide orogeny. The main reservoirs are in the Tensleep Sandstone and Park City Formation and minor reservoirs are in the Mississippian Madison Limestone, MississippianPennsylvanian Amsden Formation, Triassic Chugwater Group, and Jurassic Nugget Sandstone and Sundance Formation. The traps are sealed by shale or evaporite beds of the Park City, Amsden, and Triassic Dinwoody Formations, Triassic Chugwater Group, and Jurassic Gypsum Spring Formation.

A single conventional oil and gas assessment unit (AU), the Tensleep-Park City AU, was defined for the Phosphoria TPS. Both the AU and TPS cover the entire Wind River Basin Province. Oil is produced from 18 anticlinal fields, the last of which was discovered in 1957, and the possibility of discovering new structural oil accumulations is considered to be relatively low. Nonassociated gas is produced from only two fields, but may be underexplored in the province. The discovery of new gas is more promising, but will be from deep structures. The bulk of new oil and gas accumulations is dependent on the discovery of hypothesized stratigraphic traps in isolated carbonate reservoirs of the Park City Formation. Mean resource estimates for the Tensleep-Park City
\end{abstract}

Conventional Oil and Gas AU total 18 million barrels of oil, 294 billion cubic feet of gas, and 5.9 million barrels of natural gas liquids.

\section{Introduction}

The purpose of this study is to assess the potential for undiscovered oil and gas resources from the Phosphoria Total Petroleum System (TPS) in the Wind River Basin Province, Wyoming (fig. 1). The TPS approach to resource assessment used here is based on defining an area of mature source rock and all known and undiscovered reservoirs, and requires an understanding of petroleum generation, trap formation, and reservoir seal capacity, which are the primary factors needed for oil and gas accumulation to exist (Magoon and Dow, 1994). The petroleum system approach used in this assessment is different from that used in the 1995 assessment in the basin by Fox and Dolton (1996), although the methodology is similar. The Tensleep-Park City Assessment Unit (AU) defined here corresponds to the Phosphoria Formation-sourced part of the Basin Margin Subthrust, Basin Margin Anticline, and Deep Basin Structure plays (3501-3503) and to six hypothetical stratigraphic-trap plays (3506-3513) as defined in the 1995 assessment (Fox and Dolton, 1996). There have been about 425 new-field wildcats drilled since the last oil discovery in 1957 and about 275 new-field wildcats drilled since the last gas discovery in 1965 (fig. 2). No new fields have been discovered, in the years since the 1995 assessment by Fox and Dolton (1996). The assessment unit has been evaluated using concepts developed during this and previous assessments in light of any new advances in the geology of the area and by using analogs from the Bighorn Basin, Wyoming, and the Paradox Basin, Colorado, to provide insights into possible undiscovered fields. 


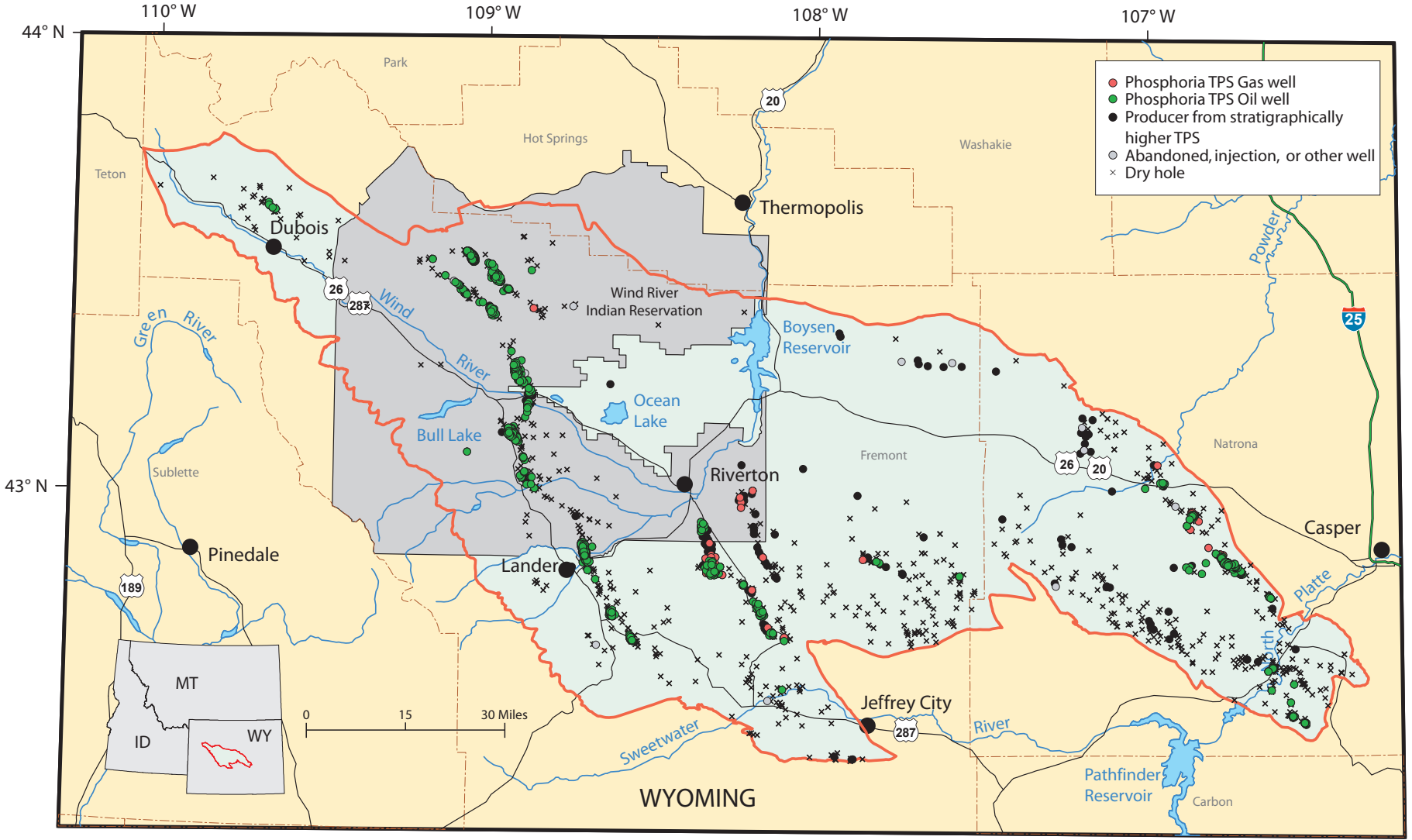

Figure 1. Index map of the Wind River Basin Province, central Wyoming, showing boundaries of Phosphoria Total Petroleum System (TPS) and Tensleep-Park City Assessment Unit (AU), (which are coincident, all within red line); Wind River Indian Reservation (gray shaded area); locations of oil and gas wells producing from the Tensleep-Park City Assessment Unit within the Phosphoria TPS and of wells that penetrate all or part of the TPS.

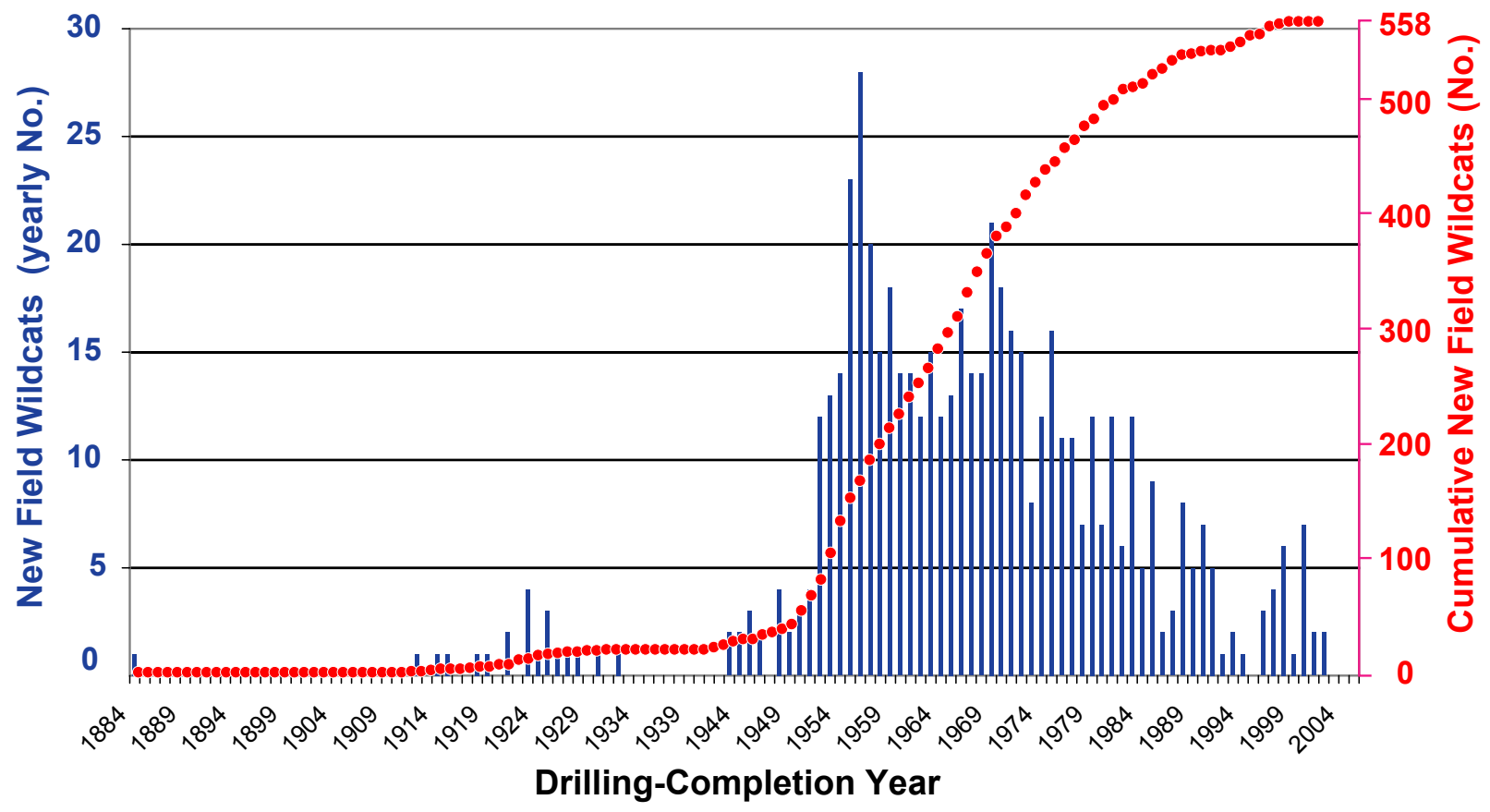

Figure 2. Histogram of number of new field wildcat wells per year (blue) and cumulative new field wildcat wells (red) for the Tensleep-Park City Oil and Gas Assessment Unit, based on data from IHS Energy Group (2005). 


\section{Structural Geology}

The Wind River Basin is surrounded by a series of northwest-trending thrust faults and anticlines and several east-west trending faults (fig. 3). The basin boundaries are defined by uplifts of the Washakie Range and Owl Creek and southern Bighorn Mountains to the north, Wind River Range to the west, Granite Mountains to the south, and Casper arch to the east (fig. 3). The main episode of deformation was during the Laramide orogeny (Blackstone, 1990).

The west margin of the basin is formed by the gently dipping northeast flank of the Wind River Range, which is bounded along its southwest flank by the Wind River thrust (fig. 3). The White Rock thrust (fig. 3) trends to the northwest out of the Wind River Range bounding the Fish Creek Basin and northwestern most margin of the Wind River Basin Province. The next thrust system to the northeast includes the Wind Ridge, Coulee Mesa, and Red Grade faults, mapped in the northwestern part of the basin (Blackstone, 1990). Another northwest-trending system is the Black Mountain thrust that terminates or continues on as the Rolff Lake thrust. The Rolff Lake thrust can be traced on seismic to the southeast for about $50 \mathrm{mi}$; the surface expression is a series of hanging wall anticlines consisting of Sheldon, Steamboat Butte, Pilot Butte, Winkleman Dome, Sage Creek, Lander, Dallas and Derby Domes with a minor southwest offset between Pilot Butte anticline and Winkleman Dome (fig. 3). The next thrust system to the northeast, called in part the Maverick Springs thrust, has a surface breakout in the Cody Shale south of Maverick Springs anticline (Love and Christiansen, 1985), is visible on seismic, and is traceable to the southeast for about

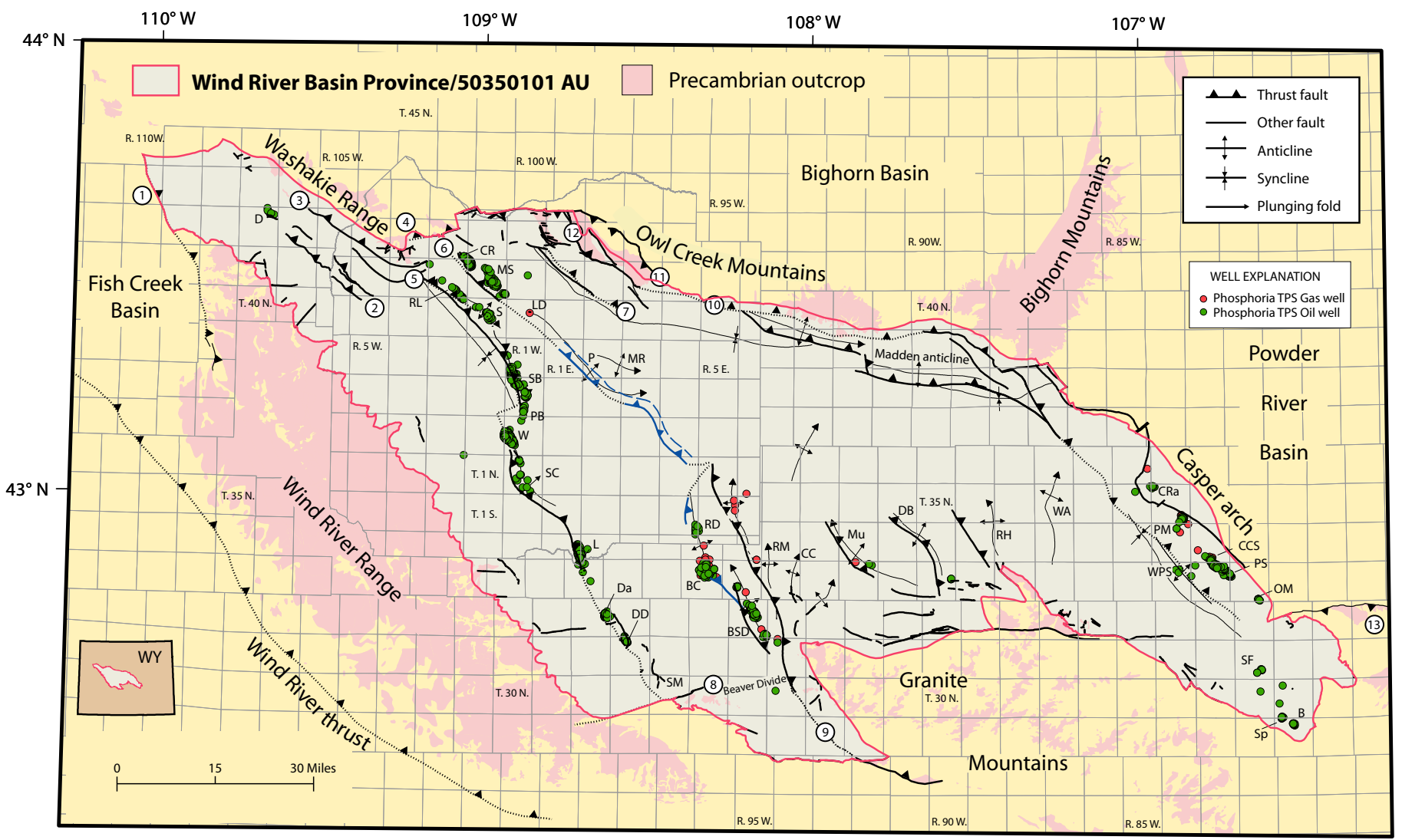

Figure 3. Generalized tectonic map of the Wind River Basin Province and adjoining areas; primary source of data is Love and Christiansen (1985). Some features dotted where inferred in subsurface. Producing wells from the Phosphoria Total Petroleum System (TPS) are shown to help delineate structures. Blue lines are approximate locations of thrust faults determined from 2-D seismic sections; solid at the fault tip; dotted at the hanging wall cutoffs of the Park City. Labeled faults: (1) White Rock thrust; (2) Wind Ridge, Coulee Mesa, and Red Grade thrust system; (3) Black Mountain thrust; (4) Red Creek thrust (Blackstone, 1990); (5) Rolff Lake fault; (6) Circle Ridge/Maverick Springs thrust; (7) Shotgun Butte thrust; (8) Clear Creek fault; (9) Emigrant Trail fault; (10) south Owl Creek thrust fault; (11) north Owl Creek thrust fault; (12) Cottonwood Creek thrust fault; and (13) Casper Mountain fault. Field and anticline abbreviations: B, Bolton Creek; BC, Beaver Creek; BSD, Big Sand Draw; CCS, Casper Creek south; CC, Conant Creek; CR, Circle Ridge; CRa, Clark Ranch; Da, Dallas; DB, Dutton Basin; DD, Derby Dome; D, Dubois; L, Lander; LD, Little Dome; MS, Maverick Springs; Mu, Muskrat; MR, Muddy Ridge; OM, Oil Mountain; P, Pavillion; PB, Pilot Butte; PM, Pine Mountain; PS, Poison Spider; RD, Riverton Dome; RH, Rattlesnake Hills; RM, Rogers Mountain; RL, Rolff Lake; S, Sheldon; SB, Steamboat Butte; SC, Sage Creek; SF, Schrader Flats; SM, Sheep Mountain; Sp, Spindletop; WA, Waltman arch; W, Winkleman; and WPS, West Poison Spider. 
$35 \mathrm{mi}$. The structure is defined on the surface by Circle Ridge, Maverick Springs, and Little Dome anticlines before passing beneath the Wind River Formation and extending to about T. 1N., R. 5E., where the structure apparently dies out. This fault system includes the Pavillion gas field on the hanging wall. The Maverick Springs trend approximately matches up with the Emigrant Trail thrust system and includes anticlines from Riverton Dome (east) in the north to Big Sand Draw in the south. This fault is projected under the Beaver Divide and becomes the southern thrusted margin of the Granite Mountains (Love and Christiansen, 1985). The large Riverton Dome and Beaver Creek fields also have northwest-trending thrust faults that appear on seismic to merge or terminate against the Emigrant Trail thrust (fig. 3). The northwest trend continues along the north margin of the Granite Mountains in a series of northwest-plunging folds including the Rogers Mountain/Conant Creek anticlines, the Dutton Basin anticline, and Rattlesnake Hills anticline (Keefer, 1970). These structures terminate to the south (figs. 3 and 4) against the north Granite Mountains fault system, which consists of a down-dropped block of Precambrian granite (Love, 1970). The easternmost northwest-trending structure in the basin is the Casper arch thrust, which bounds the east margin.

Three main east-west-trending structures complete the main structure of the basin and they include the Granite Mountains, Casper Mountain, and the Owl Creek Mountains. These structures follow a different orientation than most other Wind River Basin structures, and different than Laramide structures in general. Gries (1983) related these different orientations to an overall change in the stress field during the late Laramide. However, Molzer and Erslev (1995) suggested that the stress field did not change, and at least two of the structures, Casper Mountain and the Owl Creek Mountains, are the result of oblique slip. Stone (2002) also favored oblique-slip movement, with the structural pattern controlled by a preexisting Precambrian fabric reactivated during Laramide compression.

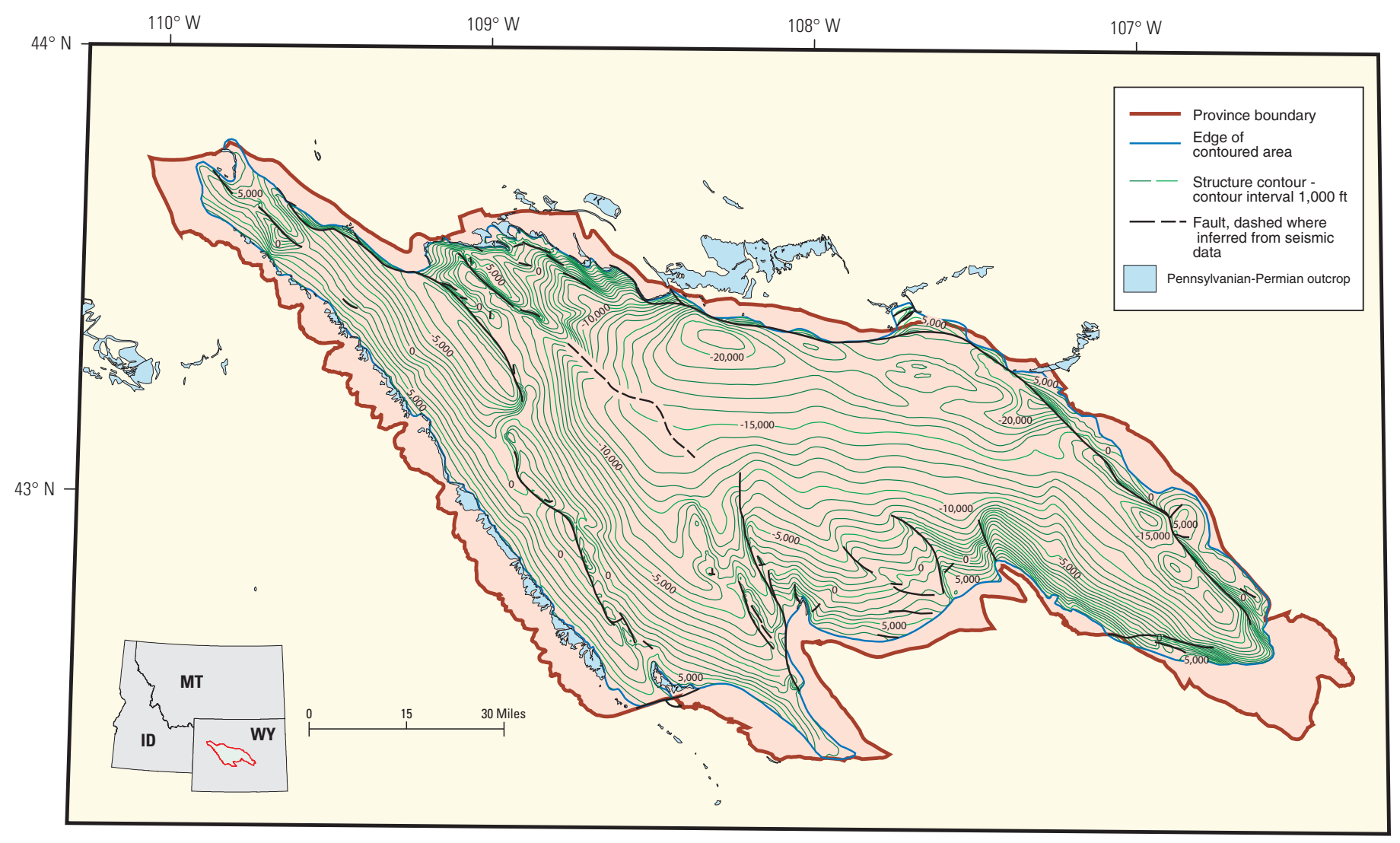

Figure 4. Major structural elements and structure contour map drawn on top of the Permian Park City Formation in the Wind River Basin Province at 1,000-ft contour intervals. Modified from Keefer (1970) and Keefer and Johnson (1993, their pl. 1), supplemented by data from wells drilled since those maps were published and from data gathered from 2-D seismic in the central part of the basin (dashed fault). 


\section{Phosphoria Total Petroleum System}

The total petroleum system (TPS) approach defines a mappable pod of mature source rock, all known and undiscovered reservoirs, and the processes and mechanisms required for oil and gas accumulations to exist (fig. 5) (Magoon and Dow, 1994). Phosphoria Formation oils produced in the Wind River Basin Province are thought to have been generated in the Wyoming and Idaho thrust belt and then migrated throughout the Wind River Basin (Sheldon, 1967; and Stone, 1967). This section of the report provides evidence that suggest the entire province is part of the TPS. The main pathway for moving the oil from the thrust belt into the Wind River Basin was most likely the Tensleep Sandstone (Sheldon, 1967; Stone, 1967) although those authors also considered the possibility of migration in Park City Formation carbonates. There is only limited mixing of Phosphoriasourced oil with other oil types (see Oil Characterization and Distribution) probably because of good sealing capacity of the rocks between the main reservoir units of this TPS and the next good overlying source rock, the Cretaceous Mowry Shale (fig. 6). The main reservoirs are sandstones of the Tensleep Sandstone and carbonates of the Park City Formation.

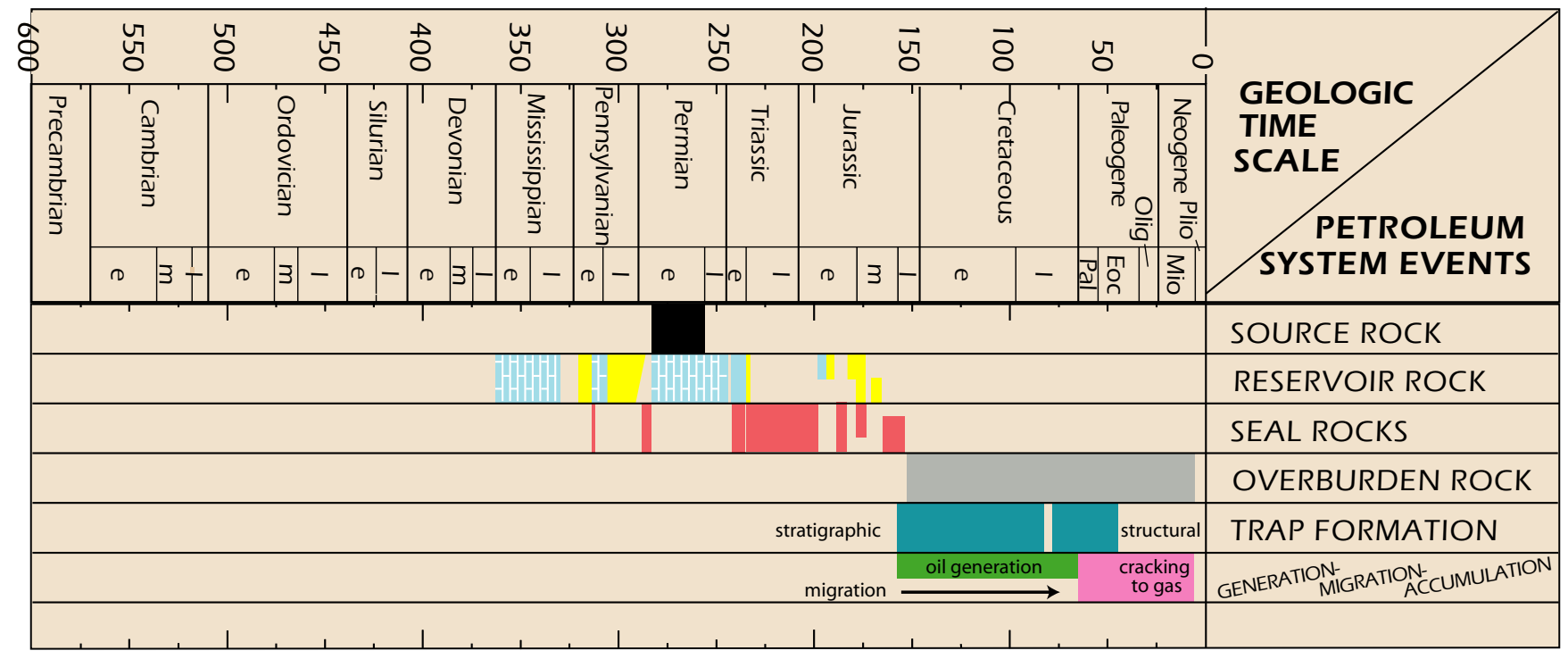

Figure 5. Petroleum system events chart for the Tensleep-Park City Conventional Oil and Gas Assessment Unit. Abbreviations: e, Early; m, Middle; I , Late; Pal, Paleocene; Eoc, Eocene; Olig, Oligocene; Mio, Miocene; Plio, Pliocene.

Petroleum system elements $\square$ Hiatus

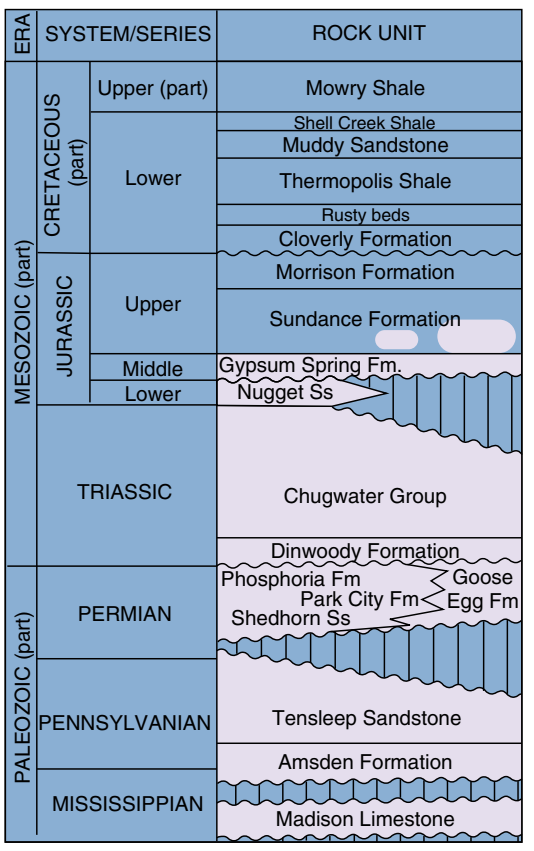

\begin{tabular}{lll} 
Main reservoir units ${ }^{1}$ & Gas & Oil \\
\hline Nugget & $<1 \%$ & $3 \%$ \\
Chugwater & $<1 \%$ & $<1 \%$ \\
Park City & $5.5 \%$ & $18 \%$ \\
Tensleep & $1 \%$ & $48 \%$ \\
Amsden & $<1 \%$ & $<1 \%$ \\
Madison (excluding Madden) & $<1 \%$ & $9 \%$ \\
\hline \multirow{3}{*}{$\begin{array}{l}\text { (Includes equivalents and all members that are unequivocally } \\
\text { from the unit listed) }\end{array}$} &
\end{tabular}

Figure 6. Diagrammatic columnar section of the Phosphoria Total Petroleum System (TPS) in the Wind River Basin Province; modified from Fox and Dolton (1996). Lighter shading represents formations that constitute petroleum system elements (source rocks, reservoirs, and seals). Table shows approximate percentages of cumulative oil and gas production from reservoir units of the Phosphoria TPS relative to total cumulative production for all TPSs in the province (data from IHS Energy Group, 2005). The total gas production in the basin is about 3.5 trillion cubic feet of gas and about 488 million barrels of oil (data from IHS Energy Group, 2005). 


\section{Source Rocks}

Organic-rich black shales of the Permian Phosphoria Formation are thought to be the source for petroleum found in upper Paleozoic and lower Mesozoic reservoirs of the Wind River Basin (Barbat, 1967; Sheldon, 1967; Maughan, 1984). The black shale facies of the Phosphoria consists of the Meade Peak and Retort Phosphatic Shale Members (fig. 7) (Maughan, 1984). Organic carbon averages about 8 weight percent for the Meade Peak in western Wyoming and about 9 weight percent for the Retort in southwestern Montana (Maughan, 1984, his fig. 5). Within the Wind River Basin Province itself, the Phosphoria is thin but locally also is rich in organic carbon, with the Meade Peak containing between $<0.1$ to 0.4 percent total organic carbon (TOC) in three surface samples, and the Retort containing 1.6 to 2.9 percent TOC in outcrop samples at Stony Point in the western part of the basin (Maughan, 1976;
Claypool and others, 1978). Just west of the basin margin near Jackson, Wyoming, the Retort ranges from slightly less than 3 to almost 6 weight percent TOC (Hiatt, 1997). Ten samples collected from the Phosphoria about 30 to 35 miles east of Lander (figs. 1 and 7), have inorganic carbon contents ranging from 0.41 to 1.48 weight percent (Medrano and Piper, 1995, Conant Creek section)

\section{Oil Characterization and Distribution}

Oils believed to be derived from the Phosphoria Formation have been previously identified and characterized in the Wind River Basin using bulk properties and molecular composition including API gravity, sulfur content, nickel/ vanadium values, stable carbon and sulfur isotope composition and biomarker composition (Bartram, 1934; Hunt, 1953;

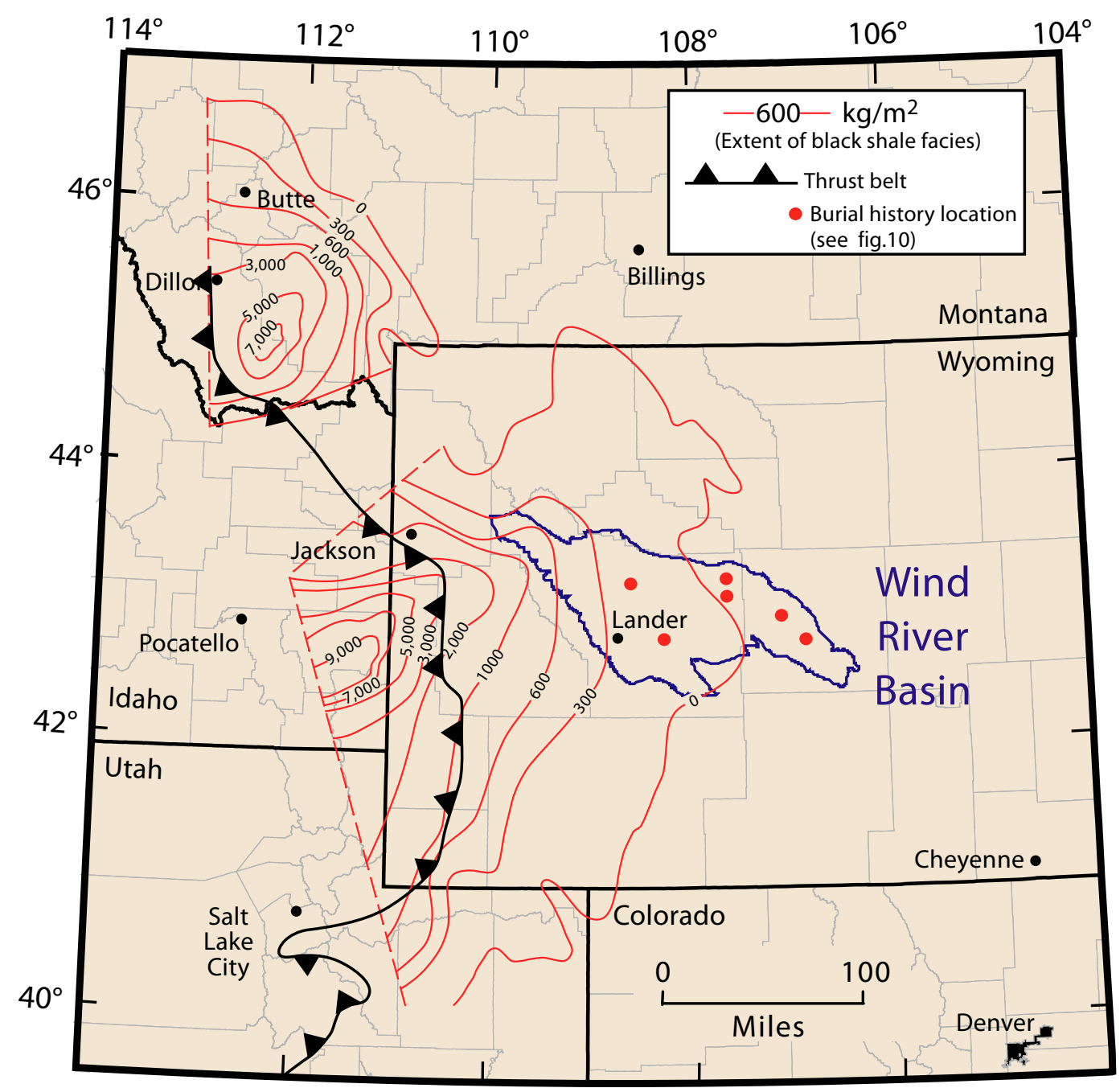

Figure 7. Distribution of organic carbon content in the black shale facies of the Phosphoria Formation; modified from Claypool and others (1978). Contour values are determined by multiplying the thickness of black shale facies by the organic carbon content, and that product by the average density of rock, to give a total organic carbon content in kilograms per unit area $\left(\mathrm{kg} / \mathrm{m}^{2}\right)$. The map essentially shows the extent of possible source rocks within the Phosphoria Formation, (primarily in the Meade Peak and Retort Phosphatic Shale Members). Also shown are locations where burial history curves were generated within the province (see fig. 10). 
Hunt and Forsman, 1957; Brenneman and Smith, 1958; McIver 1962; Vredenburgh and Cheney, 1971; Palacas and others, 1994; Silliman and others, 2002). Recent analyses by the USGS, various scientific reports, and proprietary data (GeoMark Research, Inc., 2004) were used in the current study to further characterize the Phosphoria-type oil and to map the extent of the Phosphoria petroleum system in the basin.

Phosphoria-type oil is distinguished by the high sulfur content in relation to API gravity (fig. 8A), low stable carbon isotope values of the saturated and aromatic hydrocarbon fraction (fig. 8B), and low pristane/phytane values $(<1.0)$. High sulfur oil is generated in the Phosphoria Formation because of Type-IIS kerogen as defined by Orr (1986), based on an S/C ratio greater than 0.04 (Lewan, 1985). In general, this oil type is found in Paleozoic to Lower Jurassic reservoir rocks; whereas, Mowry oil type, the next younger principal oil type in central Wyoming, is found in Upper Jurassic to Cretaceous reservoir rocks. However, in the southeastern portion of the basin, the Upper Jurassic Sundance Formation is charged with Phosphoria oil at Bolton Creek and Spindletop fields, but at Poison Spider field the Sundance reservoir contains a mixture of Phosphoria and Mowry oils. There are also examples where Mowry oil is present in older rocks- (1) Sheldon field (fig. 3), the Lower Jurassic Nugget Sandstone contains Mowry or mixed Mowry-Phosphoria oil types; (2) the eastern part of the basin, the Pennsylvanian Tensleep Sandstone contains Mowry oil at Pine Mountain; and (3) on the Casper arch, the Tensleep contains mixed MowryPhosphoria oil at Clark Ranch field (fig. 3) and Notches field, which is located east of the province boundary on the Casper arch.

\section{Maturation and Migration}

The Phosphoria Formation has long been thought to have generated petroleum in the Idaho/Wyoming part of the thrust belt and the fluids migrated long distances into central Wyoming (Sheldon, 1967; Stone, 1967). The black shales in the Meade Peak (fig. 9) are thermally mature in much of western Wyoming and southeastern Idaho (Burtner and Nigrini, 1994; Roberts and others, 2004), however, shales in the Retort Member are immature in western Montana (Claypool and others, 1978). Phosphoria black shales in the western part of the Wind River Basin, although thermally mature (fig. 10), have low TOC content (fig. 7). The timing of generation and migration of Phosphoria oil from the IdahoWyoming border has been proposed to be prior to Laramide deformation (Cheney and Sheldon, 1959; Sheldon, 1967; Stone, 1967; Maughan, 1976; Claypool and others, 1978). More recently, the Phosphoria is thought to have generated petroleum from the Idaho/Wyoming thrust belt and Green River Basin, perhaps continuously, through a series of successive events associated with the movement of fluids in advance of a sequence of eastward-moving thrust sheets during the Sevier orogeny (Burtner and Nigrini, 1994).

Maughan (1984) showed multiple pathways into the Wind River Basin from the thrust belt and even from the northern margin of the basin. For a thorough historical summary of the migration history see Johnson (2005). Conduits for the long distance migration of the petroleum generated from the Phosphoria are hypothesized to include the continuous eolian sandstones of the Tensleep Sandstone (fig. 9) and marine carbonates of the Park City Formation (Sheldon,
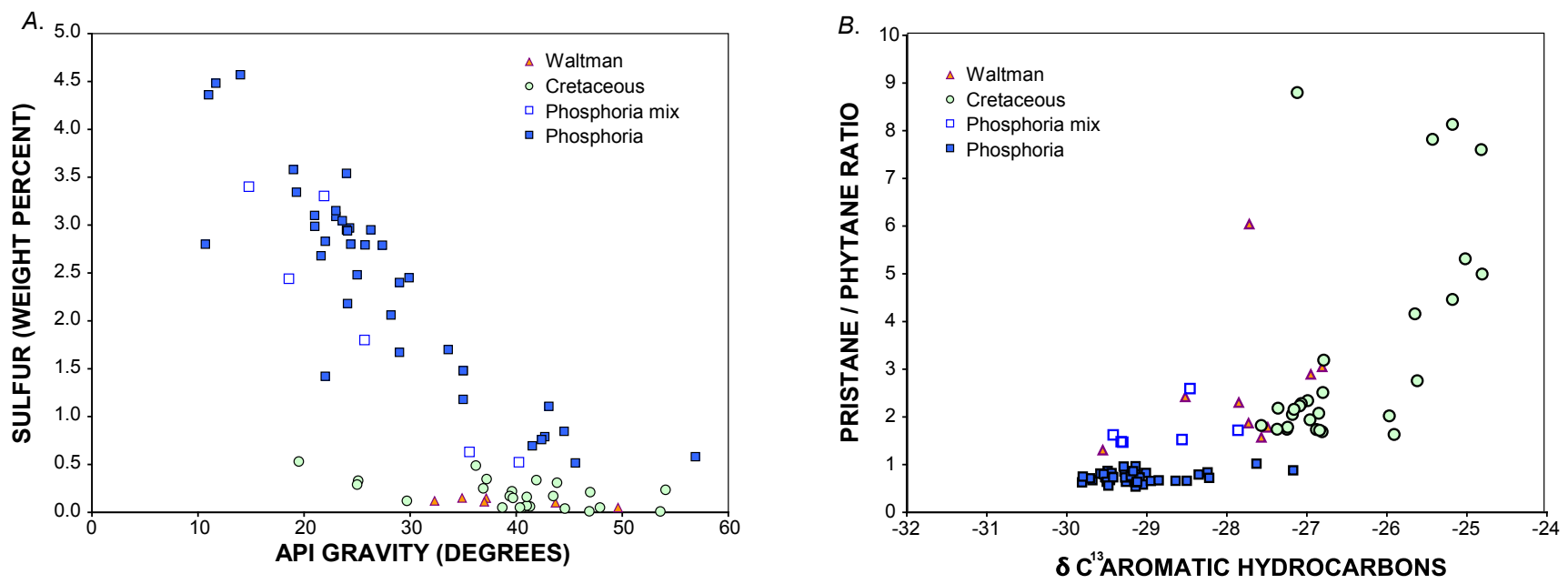

Figure 8. A, Plot of API (American Petroleum Institute) gravity versus sulfur content for oil samples from the Wind River Basin; Phosphoria oils contain moderate to high sulfur content (greater than 0.5 percent) as a function of $\mathrm{API}$ gravity. $B, \mathrm{Plot}$ of $\delta \mathrm{C}^{13}$ aromatic hydrocarbons versus pristane/phytane of oils from the Wind River Basin. Phosphoria oils have pristane/phytane values less than one; whereas, Cretaceous oils and Phosphoria-Cretaceous mixed oils have pristane/phytane values greater than one. Data are in part from and used with the permission of GeoMark Research Inc. (2004). 


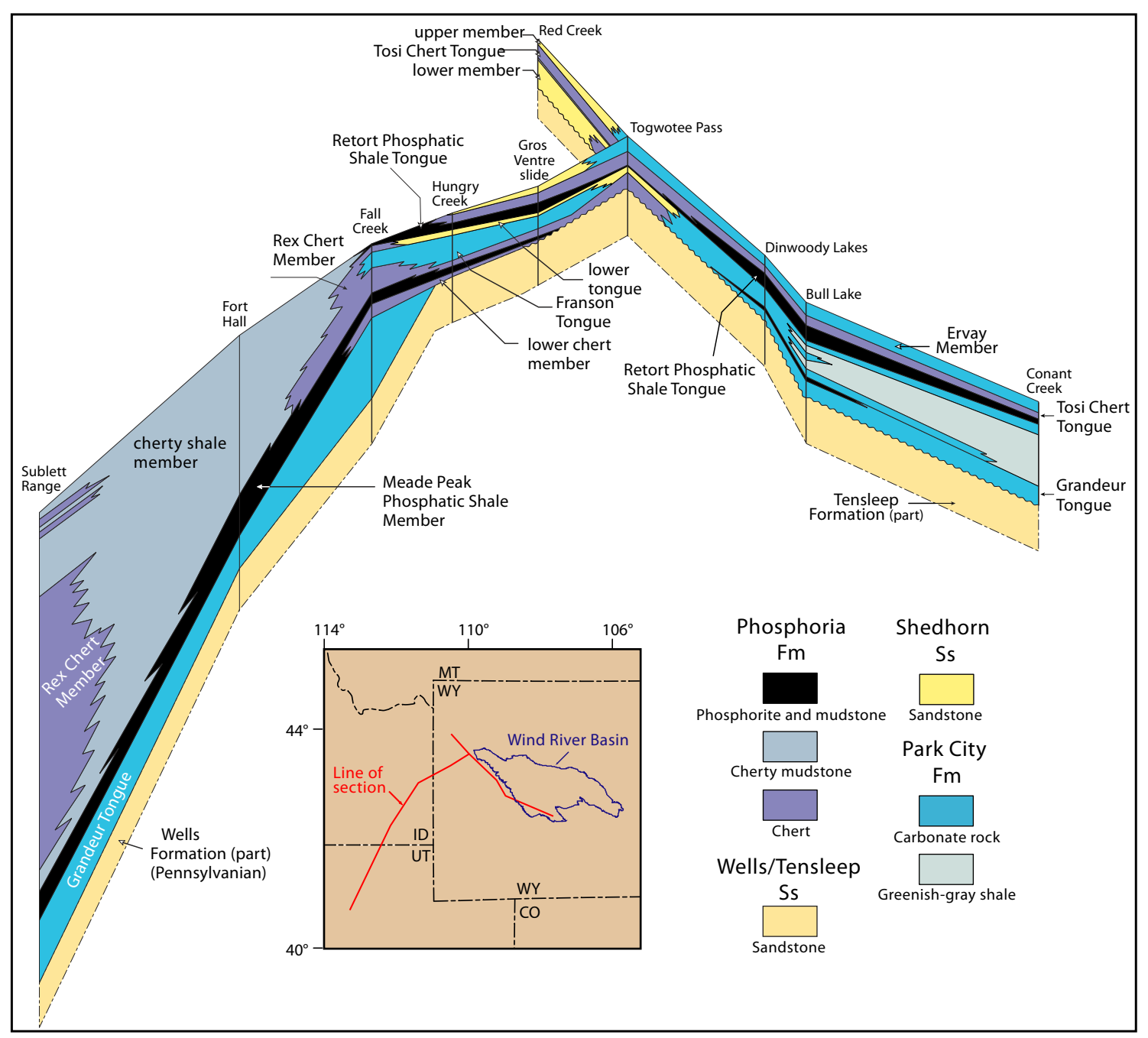

Figure 9. Segment of fence diagram modified from McKelvey and others (1959), extending from northern Utah into the western part of the Wind River Basin. Shown are distribution and relative thicknesses of various units in the Permian Phosphoria Formation and equivalent strata and the upper part of the Pennsylvanian-Permian Wells and Tensleep Sandstones.

1967; Stone, 1967). In light of the more discontinuous nature of the Park City carbonates (plate 1), the more likely main carrier bed was the Tensleep Sandstone. Fluids involved in this initial migration are interpreted to have been trapped in regional stratigraphic traps and sealed updip toward the east side of the area now occupied by the Wind River Basin, by evaporites of the Goose Egg Formation, which is a facies equivalent of the Phosphoria and Park City Formations (Stone, 1967). Keefer (1969) presented evidence that the horizon marking the Phosphoria-Tensleep contact in the Wind River Basin Province dipped to the west and southwest across the basin, which could have allowed migration of oil updip across the Casper arch and into a stratigraphic trap along the ancestral Pathfinder uplift (Mallory, 1967, his fig. 2; Mallory, 1972, p. 119). These accumulations are proposed to have remained intact within the Tensleep Sandstone and Park City Formation until Laramide structures formed in latest Cretaceous time and there was remigration of petroleum into these structures. Reservoirs stratigraphically below the Tensleep may have been filled by juxtaposition across the thrust faults. Oil pools trapped and preserved in the deepest parts of the basin during the remigration most likely have been cracked to gas (fig. 10). We use the maturation and migration model presented to explain the presence of Phosphoria-type oil in many fields producing from Permian and Pennsylvanian strata, as well as from other reservoirs in some fields, in the Phosphoria TPS in the Wind River Basin Province.

\section{Stratigraphic Units and Reservoir Rocks}

\section{Madison Limestone (Mississippian)}

The Madison Limestone consists of 600 to $700 \mathrm{ft}$ of carbonate strata in the western and northwestern parts of the Wind River Basin, but thins to about $300 \mathrm{ft}$ at the southeast 
Age (Ma)
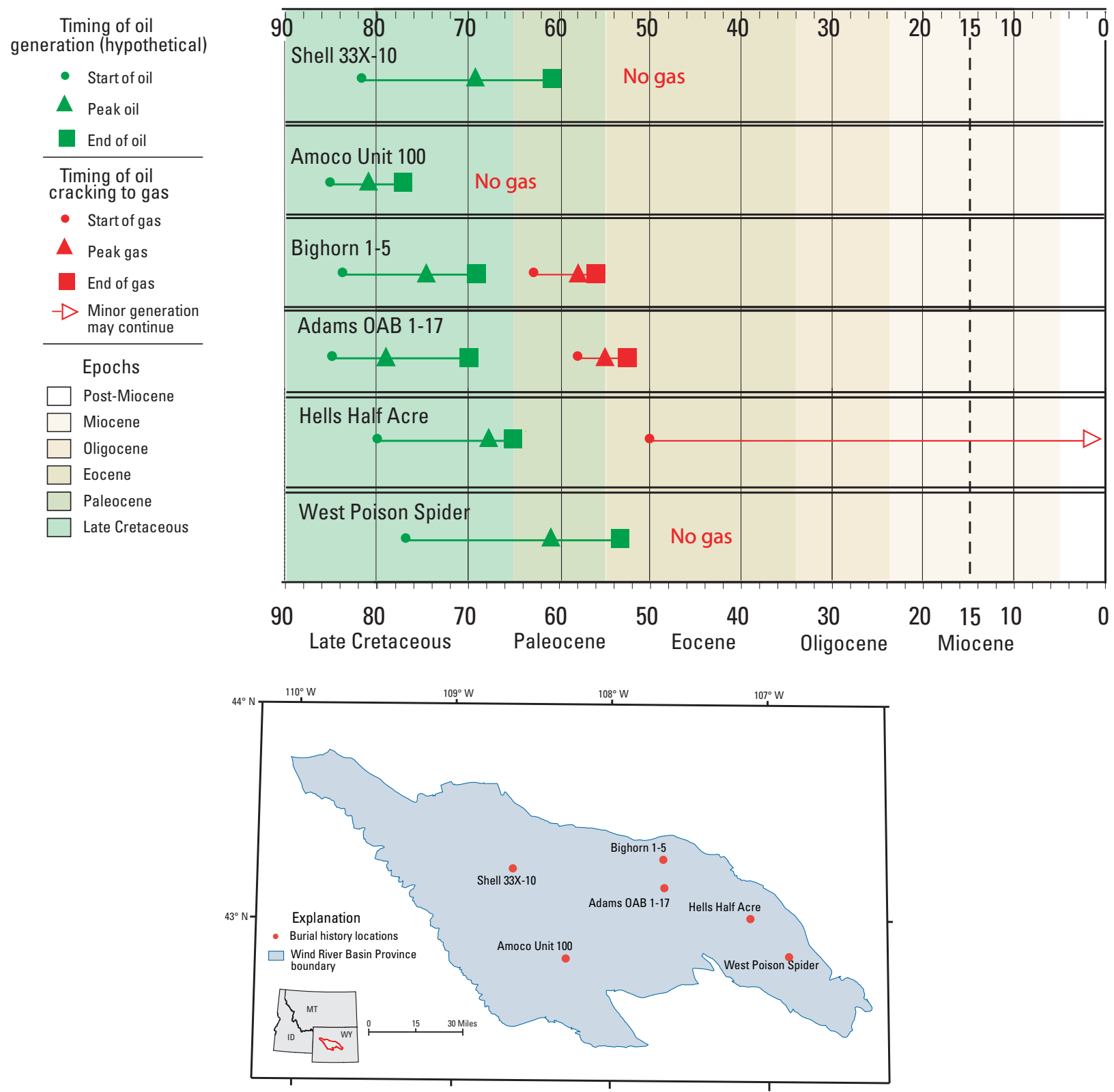

Figure 10. Plot showing timing of hypothetical oil generation from Type-IIS source rocks of the Meade Peak and Retort Phosphatic Shale Members of the Phosphoria Formation in the Wind River Basin Province. Timing of cracking to gas also is shown for hypothetical oil generated in the province and for Phosphoria-sourced oil that migrated into the province and was trapped in reservoirs of the Park City and adjacent formations. Vertical dashed line at $15 \mathrm{Ma}$ represents beginning of major regional uplift, erosion, and subsequent cooling.

corner (Keefer and Van Lieu, 1966). In the Bighorn Basin to the north, Sonnenfeld (1996) defined six 3rd order carbonate sequences deposited in outer ramp to supratidal depositional settings. Sequences are bounded by subaerial exposure surfaces at five of the six boundaries, the uppermost by an extensive karst zone and associated breccia. Westphal and others (2004) concluded that variations in reservoir quality are the result of a combination of (1) facies control, (2) a diagenetic overprint by dolomitization, and (3) a late stage hydrothermal brecciation and cementation by calcite. The uppermost sequence at Madden field in the northeastern Wind River Basin (fig. 3) is extensively brecciated limestone, making an effective seal for the lower sequences according to Westphal and others (2004). Tight lithologies at sequence boundaries act as flow barriers (Westphal and others, 2004). The Madison is a minor reservoir in the Phosphoria TPS, contributing 9 percent of the oil in the province (fig. 6). Gas produced from the Madison at Madden field is considered to be sourced from the Cretaceous-Lower Tertiary Composite TPS (Johnson and others, chapter 4, this CD-ROM). 


\section{Amsden Formation (Mississippian and Pennsylvanian)}

The Amsden Formation consists of three major units in the Wind River Basin, in ascending order the Darwin Sandstone, Horseshoe Shale, and Ranchester Limestone Members (fig. 11; Sando and others, 1975); aggregate thicknesses range from about $100 \mathrm{ft}$ to nearly $400 \mathrm{ft}$ (Keefer and Van Lieu, 1966). The formation unconformably overlies a partially karsted surface at the top of the Madison Limestone (Sando and others, 1975) and conformably underlies the Tensleep Sandstone. The Amsden and Tensleep are mapped as a single unit in some areas (Keefer and Van Lieu, 1966). An isopach map of the Darwin Sandstone Member shows a relatively sheetlike distribution, and the Darwin is thought to have been deposited by fluvial and marine processes. However, cross sections of the Darwin show distinct thin areas within the unit that were interpreted to be islands during deposition (Sando and others, 1975, p. 21, their plate 2). An alternate hypothesis could be incised valleys into the Madison that were filled with a variety of lithologies. In one core examined at the USGS core library in Denver, Colorado, (core identification number D380), the Darwin consists of crossbedded sandstone with pin-stripe lamination and thin carbonates with salt ridge structures that are interpreted as eolian dune and sabkha deposits. The Darwin Sandstone is a minor reservoir in the basin; most of the reported Amsden production is apparently from this member based on perforated zones reported in IHS Energy Group (2005).

\section{Tensleep Sandstone (Pennsylvanian)}

The Tensleep Sandstone is about 250 to $400 \mathrm{ft}$ thick (fig. 11; pl. 1) in the Wind River Basin. The Tensleep consists primarily of eolian sandstone (fig. 12A), but also contains minor dolomitic sandstone and dolostone (USGS core A693; Carr-Crabaugh and Dunn, 1996). In the Sand Draw field, the Tensleep is composed predominantly of crossbedded sandstone, much of it over-steepened, and is oil stained in core (see USGS core A693). An overlying transition zone is tightly cemented with carbonate, has no oil stain, and is the seal for the reservoir. The sandstones are carbonate cemented in this core. Regionally, the Tensleep is cemented by quartz overgrowths and (or) carbonate (Fox and others, 1975). Porosity ranges from about 5 to 22 percent and permeability ranges from 0.1 to 100 millidarcies (Fox and others, 1975, their fig. 7). Porosity decreases with depth and is generally less than 8 percent below 10,000 ft (Fox and others, 1975). A study of the internal facies in the Bighorn Basin shows the best porosity and permeability in eolian facies and the poorest in regionally extensive dolomitic sandstones (Hurley and others, 2003). These dolomitic sandstones are referred to as marine dolostones and are thought to be vertical permeability barriers, unless fracturing is present (Carr-Crabaugh and Dunn, 1996). Fracturing is an important component to fluid flow in the
Tensleep and is thought to enhance permeability, but also creates additional heterogeneity and may complicate flow units (see discussion of separate oil/water contacts in fractures and matrix in Hurley and others, 2003). Internal poikolitic dolomite cements in selected intervals of sandstone are less oil stained. Dolomitic sandstone of probable sabkha and marine (?) depositional environments are tight and are not oil stained.

The Tensleep is the most important reservoir in the Phosphoria TPS as measured by the number of wells completed ( $>500)$ and by the volume of oil produced, which is about $237 \mathrm{MMBO}$ according to IHS Energy Group (2005), or about 48 percent of the total oil produced in the Wind River Basin Province from all reservoirs (fig. 6).

\section{Phosphoria, Park City, and Goose Egg Formations (Permian)}

Permian strata, ranging in thickness from 200 to $400 \mathrm{ft}$ (Keefer and Van Lieu, 1966), are composed of three laterally equivalent formations, each representing a distinct facies in different parts of the Wind River Basin: (1) Phosphoria Formation, consisting of chert, cherty shale, and phosphatic shale at the west margin (Maughan, 1984), (2) Park City Formation, consisting of carbonates and shale across the central part (figs. 12 B and C), and (3) Goose Egg Formation, consisting of green and red shale and evaporites in the eastern part (fig. 13). There was an overall transition from open marine settings (Phosphoria, main source rock), to shallow water carbonates (Park City, main reservoir rocks), to evaporites (Goose Egg, lateral seal) from west to east across Wyoming during Permian time (fig. 13; Maughan, 1984; and Piper and Link, 2002). As previously discussed in the section on source rocks, two shale units of the Phosphoria Formation in areas mainly west of the Wind River Basin — Meade Peak and Retort Phosphatic Shale Members - are the main source rocks of the TPS.

The Park City consists, in ascending order, of the Grandeur, Franson, and Ervay Members. The Park City consists of carbonate mudstone, wackestone, packstone, grainstone, rudstone, and conglomerate and some noncarbonate siltstone, sandstone, green dolomitic shale, and chert (figs. 12 B and C) (Whalen, 1996). In the Bighorn Basin, the best reservoirs are in lower intertidal dolomite boundstone that exhibit well-connected fenestral pore space (Coalson and Inden, 1990). Peterson (1984) cites the Ervay Member as being the most productive of the Park City carbonate units because the unit was deposited as large carbonate banks, the Ervay is underlain and intertongues with the organic rich Retort Phosphatic Shale Member, and is the highest stratigraphic unit within the Park City and occupies the highest structural position in many traps.

The Park City is the second most important reservoir in the TPS contributing about 5.5 percent of the gas and about 18 percent of the oil produced in the Wind River Basin Province from reservoirs in all TPSs (fig. 6). 


\section{Dinwoody Formation (Triassic)}

The Dinwoody Formation consists of 50 to $200 \mathrm{ft}$ of calcareous shale, siltstone, and sandstone with interbedded thin limestone and red mudrock (Keefer, 1969) and lies unconformably on Permian rocks (Paull and Paull, 1986, 1987). Picard (1993) described the Dinwoody to be mostly composed of gray, green, light brown or orange siltstone with dolomite cement. The siltstone has minor sand, clay, and mica and is interbedded with anhydrite in the subsurface or with gypsum in some surface exposures. Picard (1993) also observed that the Dinwoody has higher resistivity on well logs than the overlying Chugwater rocks. Stone (1967) stated that the Dinwoody in the Bighorn Basin has little or no reservoir porosity and the little production reported from the unit is probably from the upward movement of petroleum through fractures in the crests of anticlines. In the Wind River Basin, only small amounts of oil are reported from the formation (IHS Energy Group, 2005).

\section{Chugwater Group (Triassic)}

The Chugwater Group, ranging in thickness from 1,000 to $1,300 \mathrm{ft}$ (Keefer, 1969), consists, in ascending order, of the Red Peak Formation, the Alcova Limestone, the Crow Mountain Sandstone, and the Jelm or Popo Agie Formations. With the exception of the Alcova, which is a marine limestone, the remainder of the Chugwater Group is mainly red mudrock interbedded with very fine to medium-grained sandstone (Keefer, 1957; Tohill and Picard, 1966; Picard, 1993). The Crow Mountain is thought to be of tidal flat to shallow marine origin (Tohill and Picard, 1966).

The Red Peak consists of silty claystone to sandstone and has casts of salt, mud cracks, and raindrop impressions, indicating tidal flat to nearshore marine depositional environments (Picard, 1993). The origin of other units, consisting of remarkably continuous sandstone or claystone units, is much less certain (Picard, 1993; J.D. Love, oral commun., cited in Johnson, 1993). However, continuous sandstones observed near Alcova Reservoir have irregular bedding that may be sabkha related. Other units exposed near Dubois, Wyoming, have distinct channel forms.

The Alcova Limestone consists of marine limestone and dolomite and contains minor mollusks and abundant algal structures (Picard, 1993). The unit is a minor reservoir that produces from fractured limestone with no primary porosity at Big Sand Draw field (Wyoming Geological Association, 1989).

The Crow Mountain Sandstone is characterized by fineto medium-grained crossbedded sandstone (Picard, 1993). The unit produced about 2 million barrels of oil with associated gas in the Beaver Creek, Pilot Butte, Poison Spider, Rolff Lake, Sheldon northwest, and Steamboat Butte fields (IHS Energy Group, 2005). The Crow Mountain is a minor reservoir in the province.
Fluvial deltaic siltstones and sandstones of the Jelm Formation and lacustrine mudstones and carbonates of the Popo Agie Formation are not reported to be reservoirs in the province.

\section{Nugget Sandstone (Jurassic)}

The Nugget Sandstone consists of crossbedded to rippled sandstone and minor continuous siltstone beds; it reaches a thickness of about $500 \mathrm{ft}$, but thins to zero at the east margin of the Wind River Basin (Keefer, 1969). At Derby Dome (fig. $12 \mathrm{D}$ ) it contains crossbedded sandstone of eolian origin and irregular bedded units of sabkha origin. The Nugget produces oil and associated gas mainly at Steamboat Butte and Winkleman fields, and also at Riverton east, Riverton Dome east, and Sheldon fields. Cumulative totals are only about 15 million barrels of oil and 16 to 17 billion cubic feet of gas (Wyoming Geological Association, 1989; IHS Energy Group, 2005).

\section{Gypsum Spring Formation (Jurassic)}

The Gypsum Spring Formation consists of gypsum (or anhydrite in the subsurface), red shale and siltstone, and thin limestone and dolomite beds (fig. 12 D) (Sharkey, 1946; Imlay, 1980). The Gypsum Spring is as much as $250 \mathrm{ft}$ thick in the western two-thirds of the Wind River Basin, but is absent in the eastern one-third (Keefer, 1969). The Gypsum Spring does not produce petroleum in the province. However, the most important feature of this unit, in terms of the petroleum system, is the presence of extensive anhydrite beds within the lower part of the unit that exceed $100 \mathrm{ft}$ in thickness and apparently are continuous over much of the western part of the province (fig. 12). This anhydrite unit should create an effective seal for underlying reservoirs, except where breached by faults.

\section{Sundance Formation (Jurassic)}

The Sundance Formation, 200 to $550 \mathrm{ft}$ thick, consists of interbedded sandstone and siltstone, with some limestone and shale, that were deposited in marine to eolian environments (Keefer, 1969; Picard, 1993). Some strata are glauconitic and highly fossiliferous. The unit may be effectively sealed off from Phosphoria-generated oil in the western half of the Wind River Basin by anhydrite beds in the underlying Gypsum Spring Formation. About 3.5 million barrels of oil has been produced from the Sundance at Bolton Creek, Poison Spider, Schrader Flats, and Spindletop fields (IHS Energy Group, 2005), all located at the extreme eastern margin of the province where the Gypsum Spring anhydrite beds are not present. 


\begin{tabular}{|c|c|c|}
\hline NW & - & -0 \\
\hline $\begin{array}{c}1 \\
\text { Spread Creek } \\
\text { Lower Slide Lake }\end{array}$ & $\begin{array}{l}2 \\
\begin{array}{l}\text { Wilcat } \\
\text { W.A. Moncrief JR }\end{array}\end{array}$ & $\begin{array}{c}3 \\
\text { Wildcat } \\
\text { Hel mexichave }\end{array}$ \\
\hline $\begin{array}{l}\text { Lower Side Lake } \\
\text { meaured sections }\end{array}$ & $\begin{array}{l}\text { W.A. Monchel } \\
\text { (Equitable) }\end{array}$ & $\begin{array}{l}\text { Helmerich and Payne } \\
\text { 1-16 Tribal }\end{array}$ \\
\hline 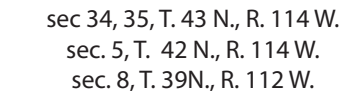 & 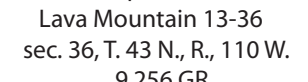 & $\begin{array}{c}\text { sec. } 16, \text { T. } .5 \mathrm{~N}, \text {, R. } 5 \mathrm{~W} . \\
6,442 \mathrm{~KB}\end{array}$ \\
\hline 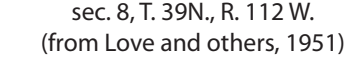 & $\begin{array}{c}9,256 \mathrm{GR} \\
\text { API } 49901321657\end{array}$ & \\
\hline
\end{tabular}

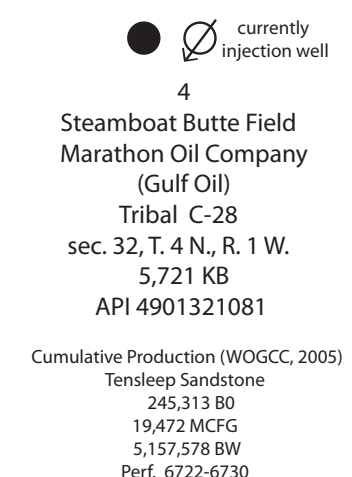

Figure 11--Stratigraphic

cross section of upper

and lower Mesozoic units

oriented northwest to south

east across the western part

of the Wind River Basin and

Fish Creek Basin (see fig. 3).

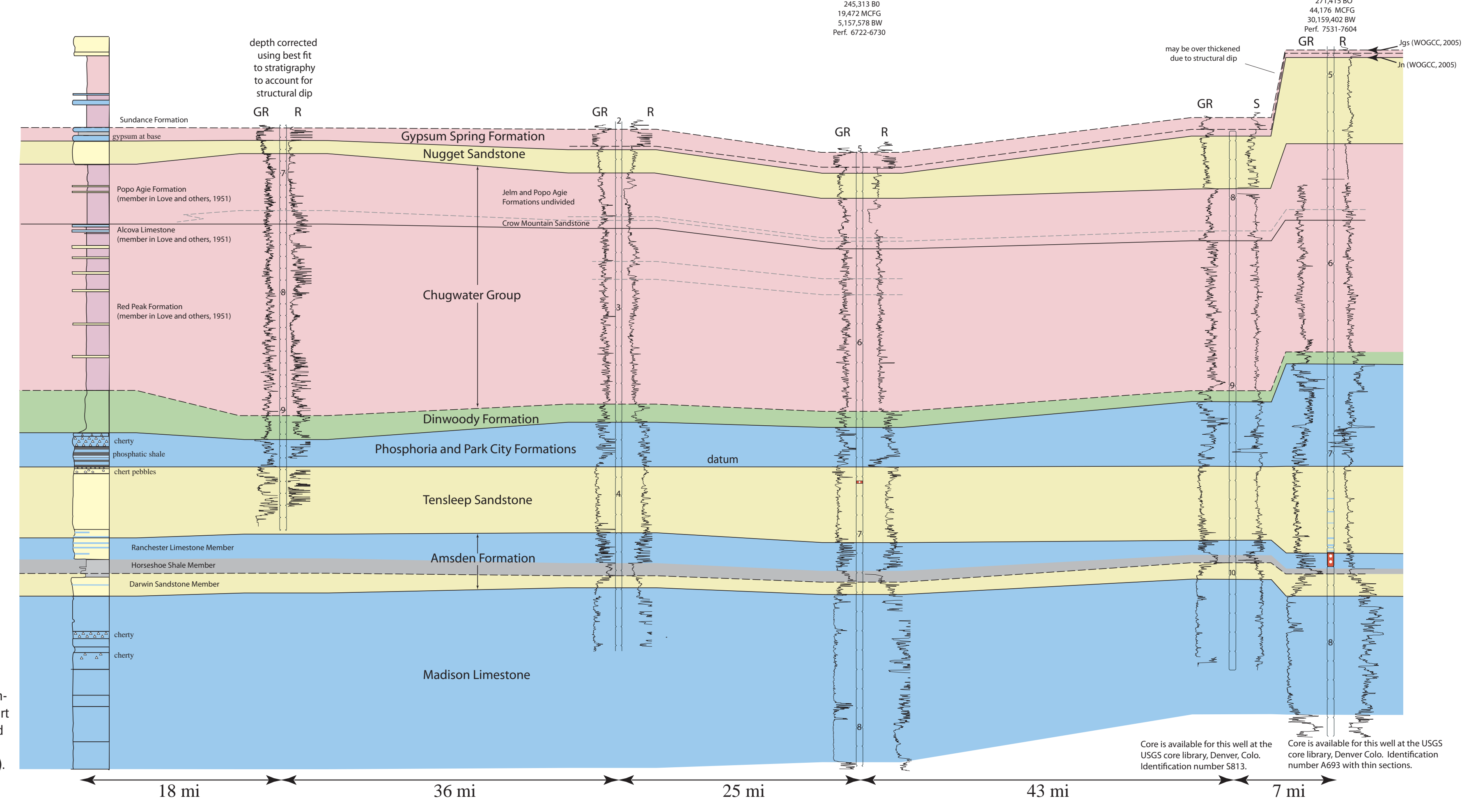




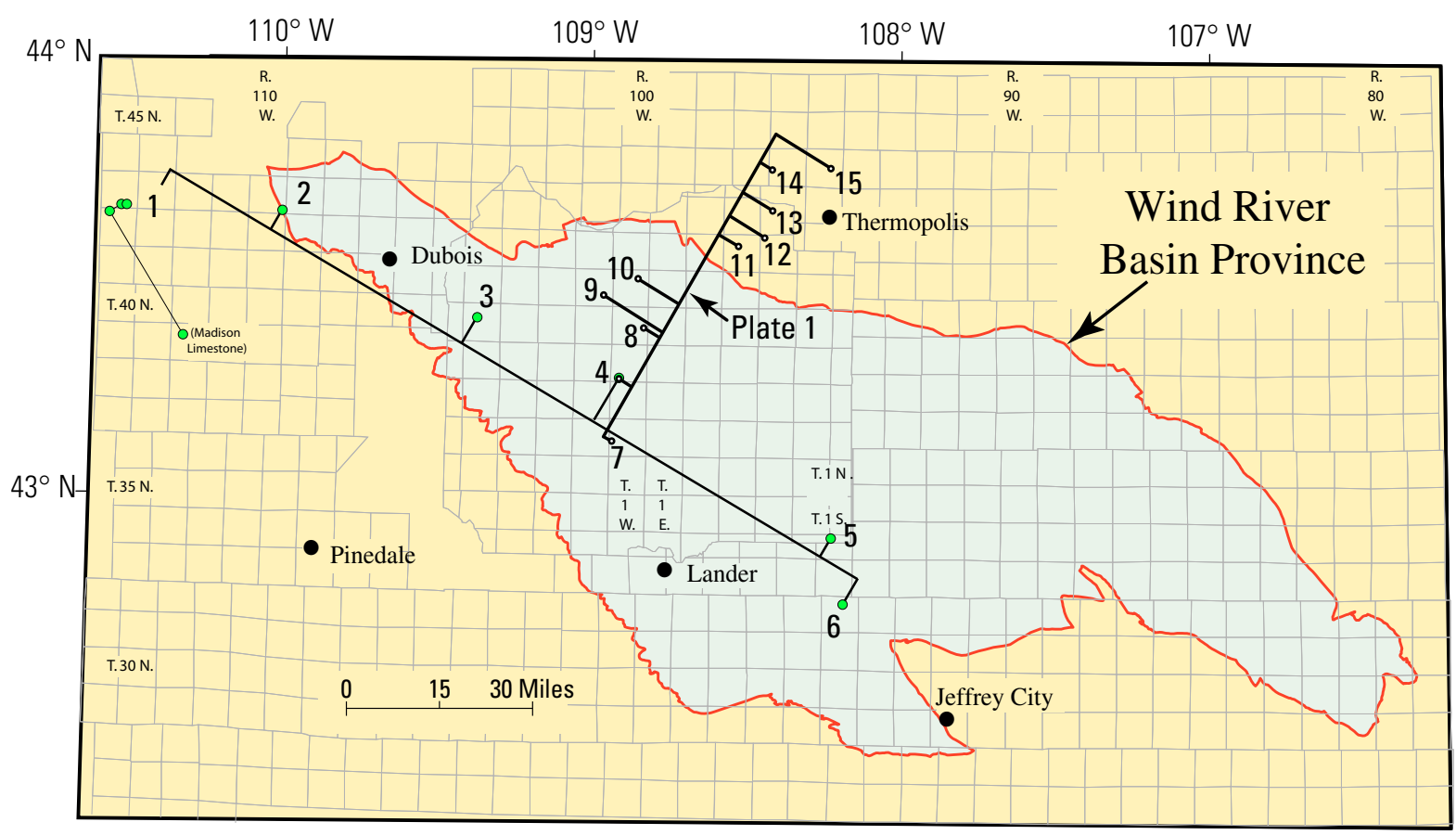

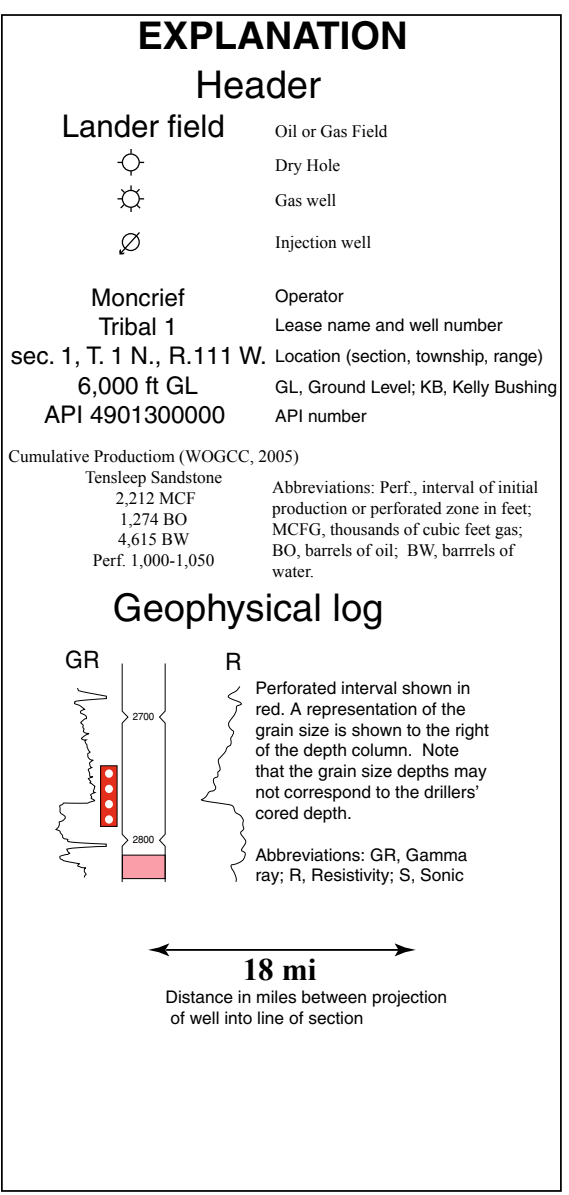

\section{Generalized depositional environments}

Predominantly marine limestone or dolomite

Predominantly eolian sandstone.

Continental or marginal marine mudrock and sandstone

Marine shale

marker horizon

Figure 11. Explanation and index map for figure $11 \mathrm{~A}$; map also shows location of cross section presented in plate 1. Datum is top of Tensleep Sandstone. Well depths are in thousands of feet. Abbreviations: Jgs, Gypsum Spring Formation; Jn, Nugget Sandstone. See figure 6 for stratigraphic chart.-Continued 

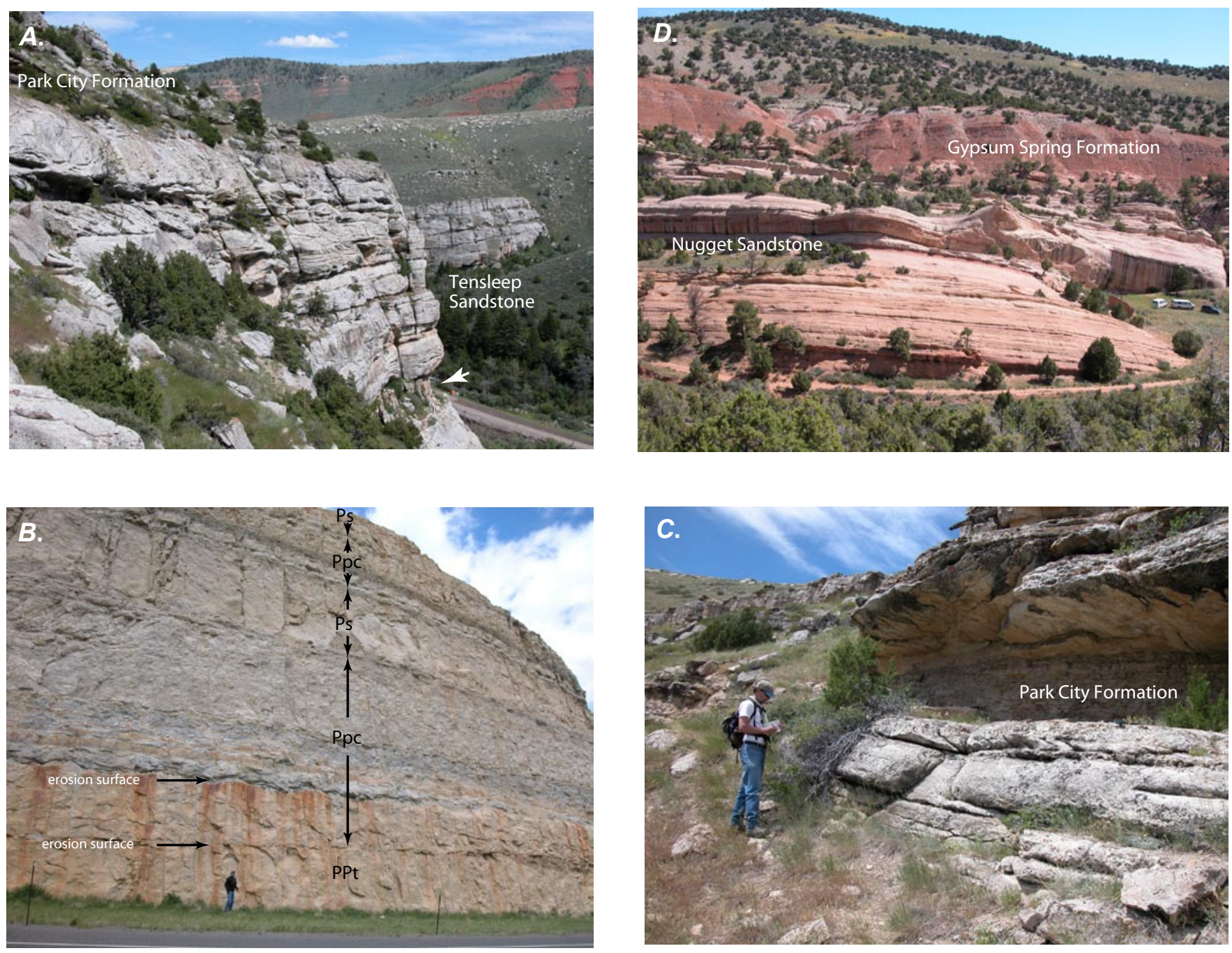

Figure 12. Photographs of main reservoir units in the Wind River Basin Province: A, view is mainly of the Tensleep Sandstone, overlain by the Park City Formation at Sinks Canyon. Indented part of outcrop (arrow) is a carbonate bed within the Tensleep that is about 20 feet thick. B, roadcut at Stony Point, located about 6 miles northwest of Dubois, Wyoming, (fig. 1) along U.S. Highway 287/26, showing uppermost Pennsylvanian to Permian Tensleep Sandstone, PPt; Permian Park City Formation, Ppc; and part of Permian Shedhorn Sandstone (?), Ps. The lower erosion surface appears to be within the Tensleep, but is defined as the base of the Park City (Keefer, 1957, p. 174). The beds above the lower erosion surface consist of chert pebbles and convolute-bedded fine-grained sandstone of fluvial (?) origin overlying upper fine-grained crossbedded sandstone of eolian (Tensleep) origin. The Park City consists of grainstone, cherty limestone, and thinly laminated phophorite (Keefer, 1957). The Shedhorn consists of fine- to medium-grained, well rounded, crossbedded sandstone of possible eolian origin. C, carbonates of the Park City Formation at Sinks Canyon, located a few miles southwest of Lander (see fig. 1). D, exposures of Nugget Sandstone and Gypsum Spring Formation near Derby Dome in the southern part of the Wind River Basin (fig. 3). The Nugget consists of interbedded medium-grained crossbedded sandstone of eolian origin and fine-grained, irregularly bedded sandstone of sabkha origin. The Gypsum Spring consists of red mudrock, bedded gypsum, and minor laminated carbonate. Note the vehicles in the far right center of the photo for scale.

\section{Traps}

As mentioned previously, oil sourced from the organicrich shales in the Phosphoria Formation are interpreted to have first accumulated in large stratigraphic traps that extended from the Bighorn Basin south into the Wind River Basin (Sheldon, 1967; Stone, 1967). With respect to the Park City Formation, possible traps were related to facies change from carbonates into evaporites of the Goose Egg Formation in both basins. Some of the traps also may have been related to the Pathfinder uplift, a poorly understood paleostructure that formed in Pennsylvanian time in the southeastern part of the Wind River Basin (Mallory, 1967, 1972). Some traps in the Wind River Basin were possibly created in the Tensleep Sandstone beneath an unconformity-forming paleotopography (fig. 12B, lower erosion surface) caused by truncation in the 

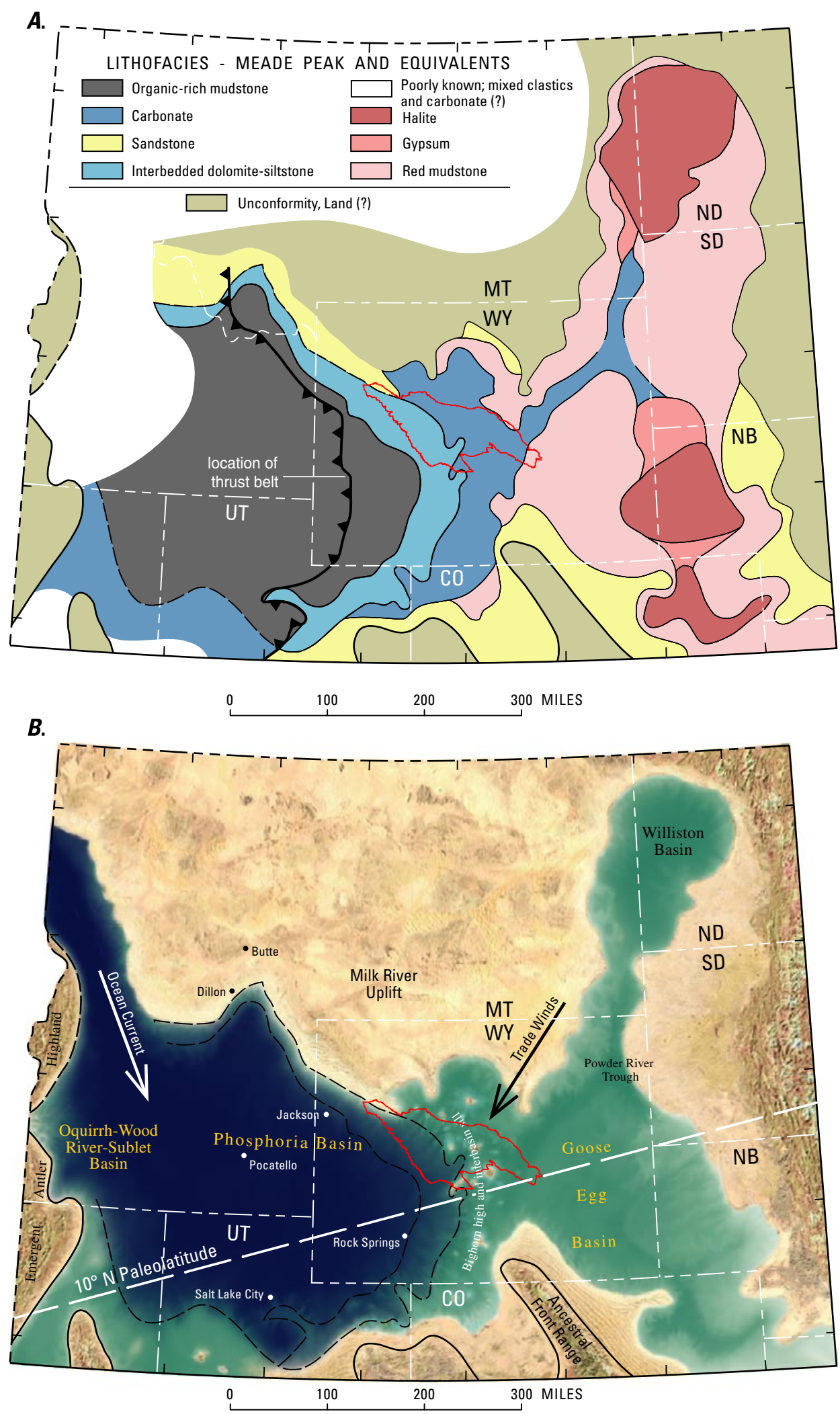

Figure 13. A, lithofacies of Meade Peak Phosphatic Shale Member of the Phosphoria Formation and equivalent rocks in Wyoming and adjacent areas from Maughan (1984). $B$, generalized paleogeographic reconstruction of the Meade Peak, based on Maughan (1984), Peterson (1988), and Piper and Link (2002). Area of Wind River Basin Province outlined in red. 
Bighorn Mountains area (Simmons and Scholle, 1990) and in the southeastern Wind River Basin (Keefer, 1969).

Remigration of the oil out of the stratigraphic traps took place during the Laramide orogeny, between the Late Cretaceous and middle Eocene, when major compressional structures were created concomitant with formation of the Wind River Basin. There are three main types of structures: (1) basin-bounding faults including the Wind River thrust, located along the southwest margin of the Wind River Range (fig. 3); the Granite Mountains structure; the Casper arch; and the Owl Creek Mountains; (2) major thrust splays, mainly off the Owl Creek Mountains (Blackstone, 1990); and (3) through-going southeast-northwest-trending thrust faults. Most of the oil and gas production from Phosphoria source rocks in the Wind River Basin Province comes from structural traps in the form of hanging wall anticlines along these through-going southeast-northwest-trending thrust systems (fig. 3).

Although there is considerable uncertainty, there may be potential undiscovered resources from stratigraphic traps in the Park City Formation. On the east side of the Bighorn Basin, the Cottonwood field is a stratigraphic trap, in which the Ervay Member of the Park City Formation produces from intertidal dolomitic boundstones and to a lesser extent from intertidal to supratidal dolomites (Coalson and Inden, 1990). These intertidal facies also are present in the Ervay, as well as in a lower unit, the Franson Member, in a north-south trending continuous band across the Wind River Basin (Ahlstrand and Peterson, 1978). However, detailed correlations (pl. 1) indicate a low degree of continuity in individual carbonate beds. Areal extents of the boundstone deposits are on the order of 160-500 acres that may coalesce over an area of about a township (Coalson and Inden, 1990). The presence of boundstone is used as evidence for the presence of a paleohigh in the Riverton Dome area (Estes-Jackson and others, 2000).

\section{Seals}

The Phosphoria TPS is separated in large part from the overlying Cretaceous-Lower Tertiary Composite TPS over much of the basin. There is small amount of leakage in a few cases. The probable main regional seal in the western part of the basin is formed by the extensive anhydrite beds in the Gypsum Spring Formation (figs. 11, 12D). This formation is absent in the eastern part of the basin, however, possibly allowing more leakage especially in the Casper arch area. Local seals in addition to the Gypsum Spring, include shale and anhydrites in the Park City, Dinwoody, and Chugwater Formations, and possible diagenetic seals in the Park City (Coalson and others, 1994) and Madison Limestone (Westphal and others, 2004).

\section{Resource Assessment}

The Phosphoria TPS consists of one AU in the Wind River Basin Province. Maximum depths to the main reservoirs (Park City and Tensleep) exceed 25,000 ft (fig. 14). Depths to producing reservoirs in the main fields of this TPS are reported to range from about $200 \mathrm{ft}$ to more than 12,000 ft (IHS Energy Group, 2005). Existing fields generally report well-established oil/water contacts (Wyoming Geological Association, 1989) and well-defined traps, which are normally associated with discrete conventional accumulations. The petroleum system is an oil province, however, in the future there may be more potential for gas production. The AU, which covers the entire province, is an area of about 4.7 million acres. The surface ownership consists of about 1.9 million acres of Federal lands, about 1.4 million acres of private lands, 1.1 million acres of Native American lands, and about 0.3 million acres of State lands.

\section{Assessment Unit 50350101 Tensleep-Park City Conventional Oil and Gas AU}

The Tensleep-Park City Conventional Oil and Gas AU consists of oil and gas trapped mainly in reservoirs of the Tensleep Sandstone and Park City Formation. The AU has 18 oil fields over the minimum size of $0.5 \mathrm{MMBO}$ (fig. 15A) and two gas fields over the minimum size of $3 \mathrm{BCFG}$ (NRG Associates, 2005). The Beaver Creek oil and gas field did not have data available for calculating an estimated ultimate recovery (fig. 15A), but has individual wells where the production to date exceeds the minimum field size (Wyoming Oil and Gas Conservation Commission, 2005). All the discovered fields are from hanging wall anticlines associated with thrust systems within or at the edge of the province. The first oil field was discovered in 1886 and there has not been a new discovery since 1957 (fig. 15A, C). The two gas fields were discovered in the early 1960s. Most of the production is from shallow reservoirs, but reservoirs have been found as deep as 11-12,000 ft (fig. 15C). The estimated ultimate recovery for individual fields ranges from 0.9 to 117.9 MMBO. The fact that no new oil field has been discovered since 1957 and no new gas field since 1965 does not bode well for future success in this petroleum system unless a new play concept can be determined. Future success also is pessimistic when viewed in terms of new field wildcats that penetrate the TPS. About 150 new field wildcats were drilled before the last oil field was found (fig. 15B) and since then about 425 new field wildcats have been drilled with activity tailing off precipitously during the last decade (fig. 2).

Undiscovered traps may still exist, however, in deep untested structures in the basin interior; such accumulations would most likely be gas-prone based on thermal maturity, but a few may contain oil. The main basis for estimating the discovery of as many as 15 oil accumulations and 40 gas 


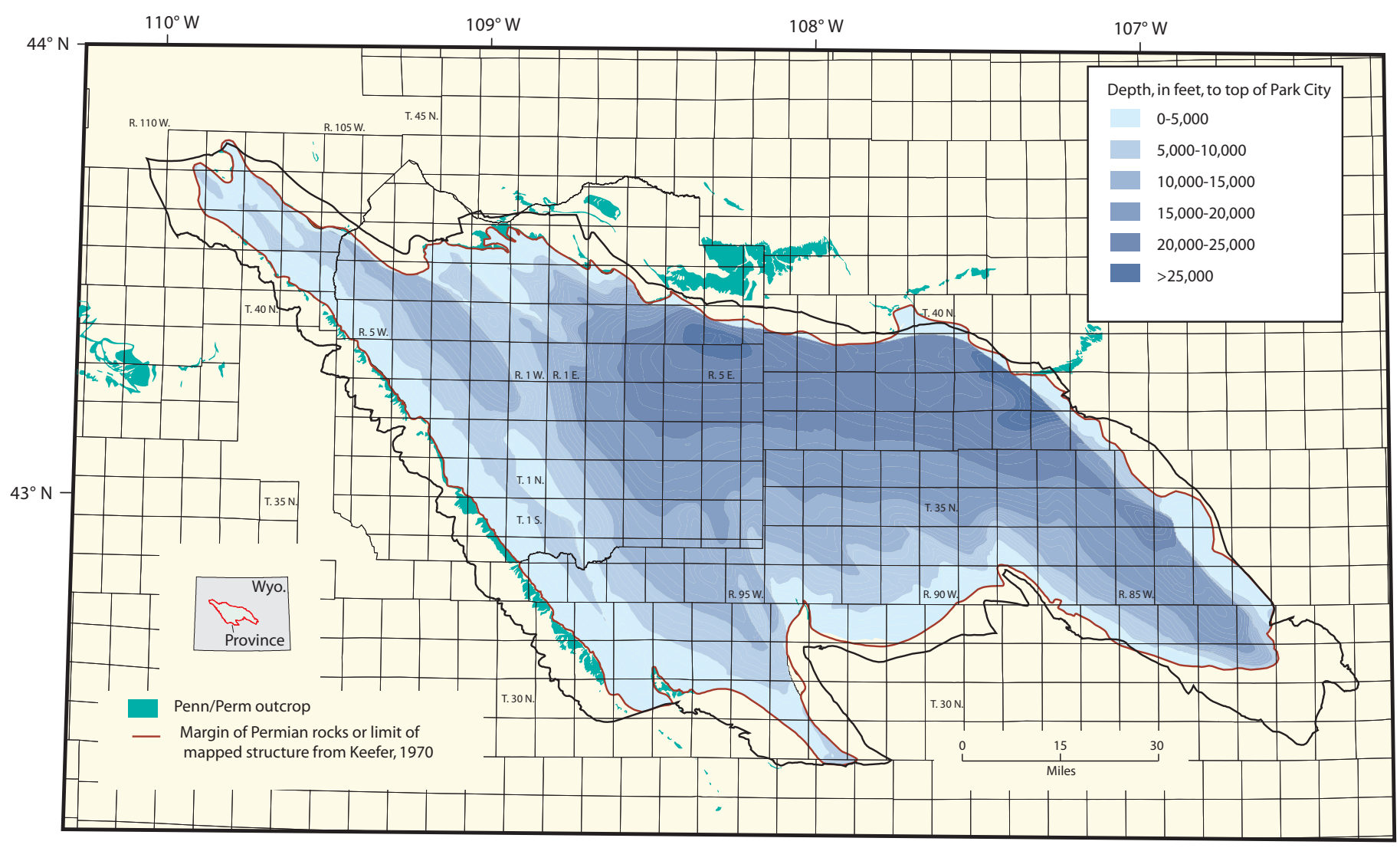

Figure 14. Depth to the top of the Park City Formation, contour interval 5,000 feet (available in the ArcGIS project at a contour interval of 1,000 feet). The map was created by subtracting the structure contour map of the top of the Park City (fig. 4) from a digital elevation model of the Wind River Basin Province.

accumulations (see Appendix A) within the Wind River Basin Province, comes from potential stratigraphic traps in the Park City Formation in the form of algal mounds or islands (fig. 16) similar to those interpreted in the Bighorn Basin (Coalson and Inden, 1990), as well as in the Paradox Basin of Colorado (Chidsey and Eby, 2004). This concept is similar to that described by Fox and Dolton (1996), but the current assessment uses a model of a shallow water sill (Piper and Link, 2002) that allowed buildups similar to the small, 0.7 to $2 \mathrm{MMBO}$, fields of the Paradox Basin (Chidsey and Eby, 2004).

Other possible stratigraphic traps may be present in the Tensleep, as the result of being truncated beneath an unconformity along the edge of the ancestral Pathfinder uplift (approximately at the edge of the Granite mountains, see Mallory, 1967, 1972); historically, however, many tests have been made in this area without success (fig. 3). There also may be some potential in facies pinchouts of the Shedhorn Sandstone, a clastic (eolian ?) unit equivalent to the Phosphoria Formation in the northwestern part of the Wind River Basin (fig. 9), as well as hypothesized facies pinchouts within the Darwin Sandstone where the Darwin fills irregularities in the upper surface of the Madison Limestone in a way similar to the Cretaceous Muddy Sandstone, which is a prolific oil producer in the basin (see cross sections of Sando and others, 1975, their pl. 2).
The sizes of undiscovered fields were determined on the basis of analogies with stratigraphic traps in the Permian Park City Formation in the Bighorn Basin and the Pennsylvanian Paradox Formation in the Paradox Basin. The median of 1.5 MMBO was estimated from typical fields in carbonate buildups in the Paradox Formation, which range from about 0.7 to 2 MMBO (Chidsey and Eby, 2004). The maximum field size of $50 \mathrm{MMBO}$ was conservatively reduced from cumulative production at Cottonwood field in the Bighorn Basin, which has produced about 65 MMBO (Wyoming Oil and Gas Conservation Commission, November, 2005). The gas median and maximum numbers were derived by using the gas equivalents of the oil accumulations.

\section{Assessment Results}

Undiscovered oil fields in the Tensleep-Park City Conventional Oil and Gas AU are estimated to contain means of $18 \mathrm{MMBO}, 19 \mathrm{BCF}$ of associated gas, and 0.4 MMB of associated natural gas liquids (table 1 ). Undiscovered gas fields are estimated at the mean to be $275 \mathrm{BCFG}$ and 5.5 MMB of natural gas liquids (table 1). 

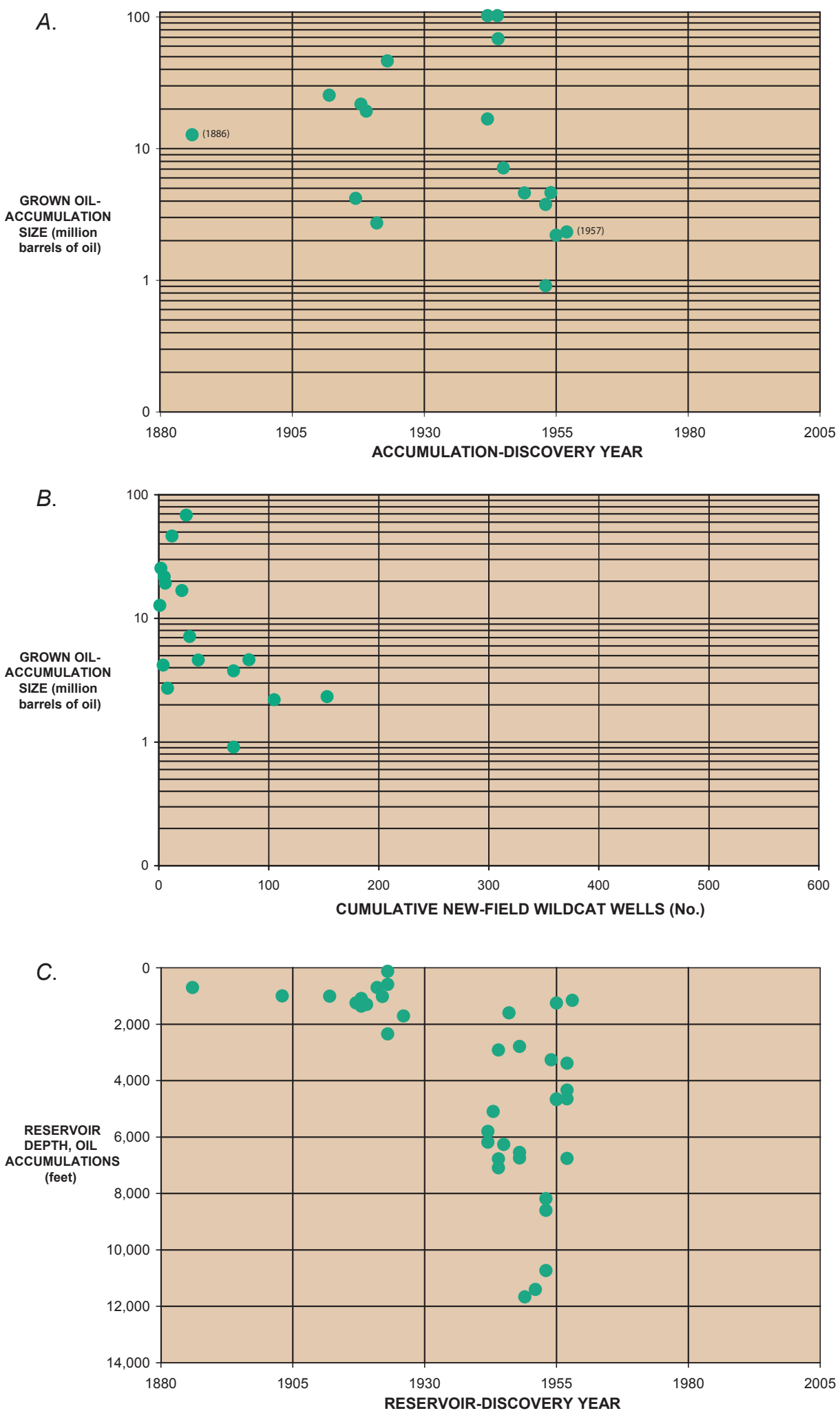

Figure 15. A, plot showing size of grown oil accumulations (fields) relative to discovery year for the Park City-Tensleep Conventional Oil and Gas Assessment Unit 50350101. Data from NRG Associates (2005). Grown accumulations refer to the estimated ultimate recovery of a field. $B$, plot showing size of grown oil accumulations relative to the number of cumulative new field wildcat wells (data from IHS Energy Group, 2005). There are 558 new field wildcats drilled in this assessment unit (see fig. 2). Grown accumulations refer to the estimated ultimate recovery of a field. $C$, plot showing reservoir depth of oil accumulations relative to reservoir discovery year for the Park City-Tensleep Conventional Oil and Gas Assessment Unit. Data from NRG Associates (2005). 


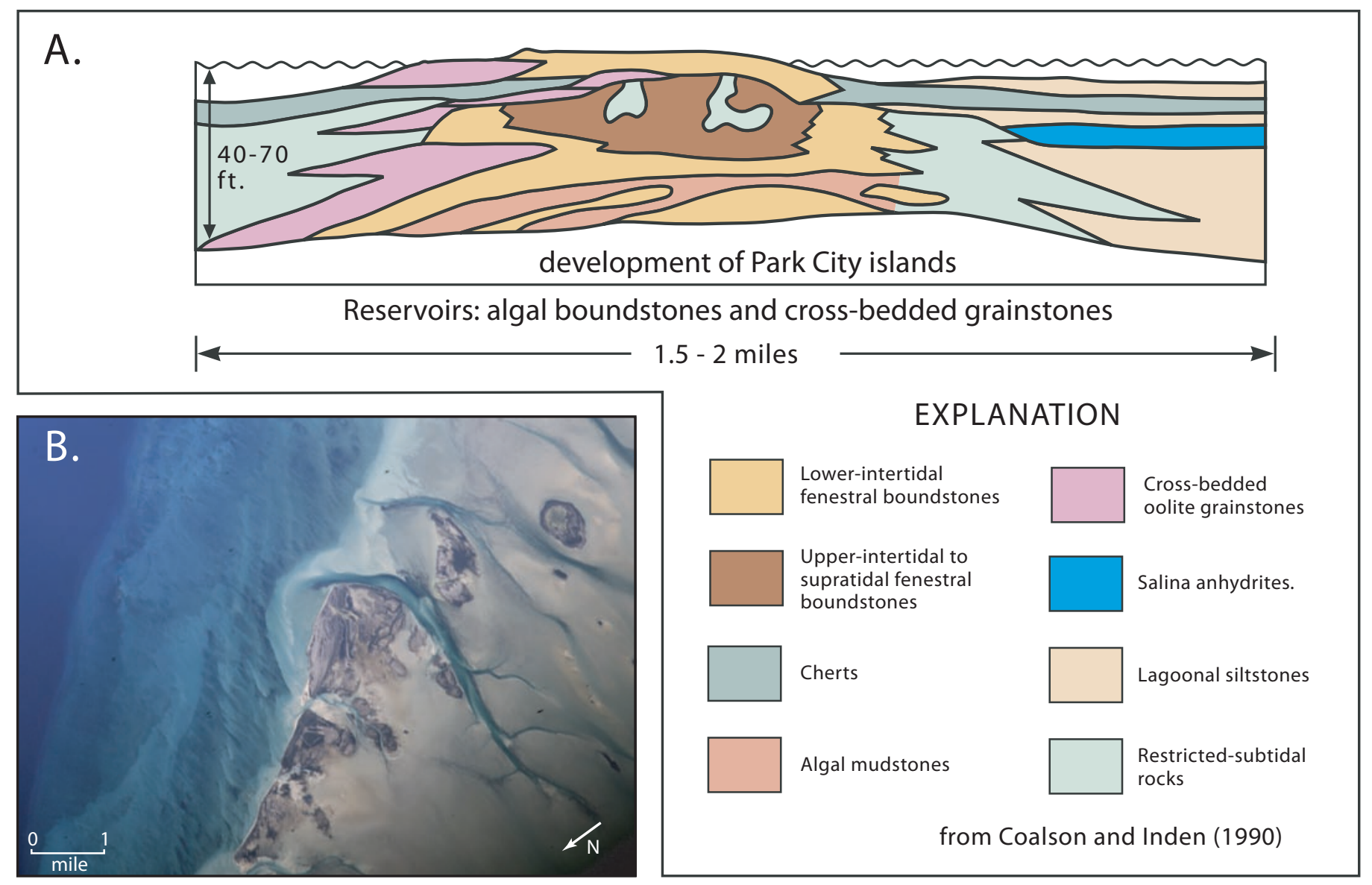

Figure 16. Depositional environment of hypothesized reservoirs for undiscovered oil and gas in the Wind River Basin Province. $A$, model for development of Park City boundstone islands interpreted to be the main reservoir at Cottonwood field in the Bighorn Basin (Coalson and Inden, 1990, their fig. 6D). B, satellite photo of Joulters Cay, Great Bahama Bank, a general analog to the Park City islands. Image courtesy of the Image Science \& Analysis Laboratory, NASA Johnson Space Center <http://eol.jsc.nasa.gov> (image number: ISS004-E-13705). Approximate scale provided.

Table 1. Summary of assessment results for the Phosphoria Total Petroleum System in the Wind River Basin Province, Wyoming. [MMBO, million barrels of oil. BCFG, billion cubic feet of gas. MBNGL, thousand barrels of natural gas liquids. Results shown are fully risked estimates. For gas fields, all liquids are included under the NGL (natural gas liquids) category. F95 represents a 95-percent chance of at least the amount tabulated. Other fractiles are defined similarly. Fractiles are additive under the assumption of perfect positive correlation. Gray shade indicates not applicable]

\begin{tabular}{|c|c|c|c|c|c|c|c|c|c|c|c|c|c|}
\hline \multirow{2}{*}{$\begin{array}{l}\text { Total Petroleum Systems } \\
\text { (TPS) } \\
\text { and Assessment Units (AU) }\end{array}$} & \multirow{2}{*}{$\begin{array}{l}\text { Field } \\
\text { type }\end{array}$} & \multicolumn{4}{|c|}{ Oil (MMBO) } & \multicolumn{4}{|c|}{$\begin{array}{c}\text { Total undiscovered resources } \\
\text { Gas (BCFG) }\end{array}$} & \multicolumn{4}{|c|}{ NGL (MBNGL) } \\
\hline & & F95 & $\mathrm{F} 50$ & F5 & Mean & F95 & F50 & F5 & Mean & F95 & F50 & F5 & Mean \\
\hline \multicolumn{14}{|l|}{ Phosphoria TPS } \\
\hline \multirow{2}{*}{$\begin{array}{l}\text { Tensleep-Park City Conventional } \\
\text { Oil and Gas AU }\end{array}$} & Oil & 4 & 16 & 42 & 18 & 4 & 15 & 44 & 19 & 90 & 360 & 1,090 & 440 \\
\hline & Gas & & & & & 56 & 244 & 600 & 275 & 1,040 & 4,710 & 12,550 & 5,490 \\
\hline $\begin{array}{l}\text { Total Undiscovered } \\
\text { Oil and Gas Resources }\end{array}$ & & 4 & 16 & 42 & 18 & 60 & 259 & 644 & 294 & 1,130 & 5,070 & 13,640 & 5,930 \\
\hline
\end{tabular}




\section{Acknowledgments}

We thank the following individuals for contributions to this report: Chris Anderson, U.S. Geological Survey contractor, for GIS analysis; Jeannine Honey of the USGS core library for help in locating cores; Wayne Husband, U.S. Geological Survey contractor, for layout and graphic design; Tim Klett for his work on production plots; Kreig Lyles, USGS contractor, graphic design of Phosphoria paleogeography and general drafting; Dick Keefer for numerous discussions on the geology of the basin; Jim Palacas for compilation and discussions of geochemical data; Chris Potter for discussions of structural geology; Chris Schenk for discussions of petroleum systems, eolian systems in the field, and for providing photographs in figure 12; Dave Taylor for making 2-D seismic sections available. We gratefully acknowledge GeoMark Research Inc. for permission to publish plots of their petroleum geochemistry data. Reviews by Steve Condon, Jim Palacas, and Ofori Pearson and editing by Dick Keefer greatly improved the manuscript. An edit of geologic names by Doug Nichols is appreciated. Lyn Osburn edited the final draft.

\section{References}

Ahlstrand, D.C., and Peterson, J.A., 1978, Permian carbonate facies, Wind River Basin, Wyoming, in Boyd, R.G., Olson, G.M., and Boberg, W.W., eds., Resources of the Wind River Basin: Wyoming Geological Association 30th Annual Field Conference Guidebook, p. 89-99.

Barbat, W.N., 1967, Crude-oil correlations and their role in exploration: American Association of Petroleum Geologists Bulletin, v. 51, no. 7, p. 1255-1292.

Bartram, J.G., 1934, Oil gravities in the Rocky Mountain states, in Wrather, W.E., and Lahee, F.H., eds., Problems in Petroleum Geology: American Association of Petroleum Geologists Special Publication 6, v. A069, p. 157-176.

Blackstone, D.L. Jr., 1990, Rocky Mountain foreland structure exemplified by the Owl Creek Mountains, Bridger Range and Casper Arch, central Wyoming, in Specht, R.W., ed., Wyoming Sedimentation and Tectonics: Wyoming Geological Association Guidebook, 41st Field Conference, p. 151-166, 2 pls. in pocket.

Brenneman, M.C., and Smith, P.V. Jr., 1958, The chemical relationships between crude oils and their source rocks, in Weeks, L.G., ed., Habitat of oil: American Association of Petroleum Geologists Special Publication 18, p. 818-849.
Burtner, R.L., and Nigrini, Andrew, 1994, Thermochronology of the Idaho-Wyoming thrust belt during the Sevier Orogeny: A new, calibrated, multiprocess thermal model: American Association of Petroleum Geologists Bulletin, v. 78, no. 10 , p. 1586-1612.

Carr-Crabaugh, Mary, and Dunn, T.L., 1996, Reservoir heterogeneity as a function of accumulation and preservation dynamics, Tensleep Sandstone, Bighorn and Wind River Basins, Wyoming in Longman, M.W., and Sonnenfeld, M.D., eds., Paleozoic Systems of the Rocky Mountain Region: Rocky Mountain Section, SEPM, p. 305-320.

Cheney, T.M., and Sheldon, R.P., 1959, Permian stratigraphy and oil potential, Wyoming and Utah, in Williams, N.C., ed., Guidebook to the Geology of the Wasatch and Uinta Mountains Transition Area: Intermountain Association of Petroleum Geologists 10th Annual Field Conference, p. $90-100$.

Chidsey, Jr., T.C., and Eby, D.E., 2004, Heterogeneous shallow-shelf carbonate buildups in the Paradox Basin, Utah and Colorado: Targets for increased oil production and reserves using horizontal drilling techniques: Utah Geological Survey Semi-Annual Technical Progress Report April 6, 2004-October 5, 2004, Contract No. DE-FC26-00BC15128, $22 \mathrm{p}$.

Claypool, G. E., Love, A.H., and Maughan, E.K., 1978, Organic geochemistry, incipient metamorphism and oil generation in black shale members of the Phosphoria Formation, Western Interior United States: American Association of Petroleum Geologists Bulletin, v. 62, no. 1, p. 98-120.

Coalson, E.B., Goolsby, S.M., Franklin, M.H., 1994, Subtle seals and fluid-flow barriers in carbonate rocks, in Dolson, J.C., Hendricks, M.L., Wescott, W.A., eds., Unconformityrelated Hydrocarbons in Sedimentary Sequences; guidebook for petroleum exploration and exploitation in clastic and carbonate sediments: Rocky Mountain Association of Geologists Symposium, p. 45-58.

Coalson, E.B., and Inden, R.F., 1990, Geology and oil production of the Ervay ("Phosphoria") reservoirs, eastern Big Horn Basin, Wyoming: Mountain Geologist, v. 27, no. 3, p. 77-98.

Estes-Jackson, J.E., Shewmake, D.W., Siguaw, S.G., 2000, Changes in attitudes, changes in attributes: using 3-D seismic to identify new opportunities in old fields-Riverton Dome field, Wyoming: Mountain Geologist, v. 37, no. 1, p. 33-45.

Fox, J.E., and Dolton, G.L., 1996, Wind River Basin Province (035), in Gautier, D.L., Dolton, G.L., Takashashi, K.I., and Varnes, K.L., eds., 1995 National assessment of United States oil and gas resources-Results, methodology, and supporting data: U.S. Geological Survey Digital Data Series DDS-30, CD-ROM, release 2, 21 p. 
Fox, J.E., Lambert, P.W., Mast, R.F., Nuss, N.W., and Rein, R.D., 1975, Porosity variation in the Tensleep and its equivalent the Weber Sandstone, western Wyoming-A log and petrographic analysis, in Bolyard, D.W., ed., Deep drilling frontiers of the central Rocky Mountains: Rocky Mountain Association of Geologists Guidebook, p. 185-216.

GeoMark Research, Inc., 2004, Oil information library system: database available from GeoMark Research, Inc., 9748 Whithorn Drive, Houston, Texas, 77095, U.S.A.

Gries, Robbie, 1983, North-south compression of Rocky Mountain foreland structures, in Lowell, J.D., and Gries, Robbie, eds., Rocky Mountain Foreland Basins and Uplifts: Rocky Mountain Association of Geologists, p. 9-32.

Hiatt, E.E., 1997, A paleoceanographic model for oceanic upwelling in a Late Paleozoic epicontinental seaA chemostratigraphic analysis of the Permian Phosphoria Formation: Boulder, Colo., University of Colorado, Ph.D. dissertation, $294 \mathrm{p}$.

Hunt, J.M., 1953, Composition of crude oil and its relation to stratigraphy in Wyoming: American Association of Petroleum Geologists Bulletin, v. 37, no. 8, p.1837-1872.

Hunt, J.M. and Forsman, J.P., 1957, Relation of crude oil composition to stratigraphy in the Wind River Basin in Bibb, T.W., Jr., ed., Southwestern Wind River Basin: Wyoming Geological Association Guidebook 12th Annual Field Conference, p. 105-112.

Hurley, N.F., Aviantara, A.A., Kerr, D.R., 2003, Structural and stratigraphic compartments in a horizontal well drilled in the eolian Tensleep Sandstone, Bryon field, Wyoming, in Carr, T.R., Mason, E.P., and Feazel, C.T., eds., Horizontal wells-Focus on the reservoir: American Association of Petroleum Geologists Methods in Exploration, no. 14, p. 143-159.

IHS Energy Group, 2005, [includes data current as of December 2000] PI/Dwights Plus U.S. Production Data: Englewood, Colo., database available from IHS Energy Group, 15 Inverness Way East, D205, Englewood, CO 80112, U.S.A.

Imlay, R.W., 1980, Jurassic paleobiogeography of the conterminous United States in its continental setting: U.S. Geological Survey Professional Paper 1062, 134 p.

Johnson, E.A., 1993, Depositional history of Triassic rocks in the area of the Powder River Basin, northeastern Wyoming and southeastern Montana: U.S. Geological Survey Bulletin 1917, Chapter P, 30 p.
Johnson, E.A., 2005, Geologic assessment of undiscovered oil and gas resources in the Phosphoria Total Petroleum System, southwestern Wyoming Province, Wyoming, Colorado, and Utah, in USGS Southwestern Wyoming Province Assessment Team, Petroleum Systems and Geologic Assessment of Oil and Gas in the Southwestern Wyoming Province, Wyoming, Colorado and Utah: U.S. Geological Survey Digital Data Series DDS-69-D, Chapter 4, 46 p, CD-ROM.

Keefer, W.R., 1957, Geology of the Du Noir area Fremont County Wyoming: U.S. Geological Survey Professional Paper 294-E, p. 155-221.

Keefer, W.R., 1969, Geology of petroleum in Wind River Basin, central Wyoming: American Association of Petroleum Geologists Bulletin, v. 53, no. 9, p. 1839-1865.

Keefer, W.R., 1970, Structural geology of the Wind River Basin, Wyoming: U.S. Geological Survey Professional Paper 495-D, 35 p.

Keefer, W.R., and Johnson R.C., 1993, Stratigraphy and oil and gas resources in uppermost Cretaceous and Paleocene rocks, Wind River Reservation, Wyoming, in Keefer, W.R., Metzger, W.J., and Godwin, L.H. eds., Oil and Gas and other resources of the Wind River Basin Wyoming: Wyoming Geological Association Special Symposium 1993, p. $71-85,5$ pls in pocket.

Keefer, W.R., and Van Lieu, J.A., 1966, Paleozoic Formations in the Wind River Basin Wyoming: U.S. Geological Survey Professional Paper 495-B, 60 p.

Lewan, M.D., 1985, Evaluation of petroleum generation by hydrous pyrolysis experimentation: Philosophical Transactions of the Royal Society of London, Series A, v. 315, p. 123-134.

Love, J.D., 1970, Cenozoic geology of the Granite Mountains area, central Wyoming: U.S. Geological Survey Professional Paper 495-C, 154 p.

Love, J.D., and Christiansen, A.C., 1985, Geologic map of Wyoming: U.S. Geological Survey and Geological Survey of Wyoming 1:500,000.

Love, J.D., Keefer, W.R., Duncan, D.C., Bergquist, H.R., and Hose, R.K., 1951, Geologic map of the Spread Creek-Gros Ventre River area, Teton County, Wyoming: U.S. Geological Survey Oil and Gas Investigations Map OM-118, 2 sheets.

Magoon, L.B., and Dow, W.G., 1994, The petroleum system, in Magoon, L.B., and Dow, W.G., eds., The Petroleum System-From source to trap: American Association of Petroleum Geologists Memoir 60, p. 3-24.

Mallory, W.W., 1967, Pennsylvanian and associated rocks in Wyoming: U.S. Geological Survey Professional Paper 554$\mathrm{G}, 31 \mathrm{p}$. 
Mallory, W.W., 1972, Regional Synthesis of the Pennsylvanian System, in Mallory, W.W., ed., Geologic Atlas of the Rocky Mountain Region: Rocky Mountain Association of Geologists, p. 111-127.

Maughan, E.K., 1976, Organic carbon and selected element distribution in the phosphatic shale members of the Permian Phosphoria Formation, eastern Idaho and parts of adjacent states: U.S. Geological Survey Open-File Report 76-577, 92 p.

Maughan, E.K., 1984, Geological setting and some geochemistry of petroleum source rocks in the Permian Phosphoria Formation, in Woodward, Jane, Meissner, F.F., and Clayton, J.L., eds., Hydrocarbon Source Rocks of the Greater Rocky Mountain region: Rocky Mountain Association of Geologists, p. 281-294.

McIver, R.D., 1962, The crude oils of Wyoming-Product of depositional environment and alteration, in Enyert, R.L., and Curry, W.H., III, eds., Symposium on Early Cretaceous rocks of Wyoming and adjacent areas: Wyoming Geological Association Guidebook, 17th Annual Field Conference, p. 248-251.

McKelvey, V.E., Williams, J.S., Sheldon, R.P., Cressman, E.R., Cheney, T.M., and Swanson, R.W., 1959, The Phosphoria, Park City and Shedhorn Formations in the western phosphate field: U.S. Geological Survey Professional Paper 313A, $47 \mathrm{p}$.

Medrano, M.D., and Piper, D.Z., 1995, Partitioning of minor elements and major-element oxides between rock components and calculation of the marine derived fraction of the minor elements in rocks of the Phosphoria Formation, Idaho and Wyoming: U.S. Geological Survey Open-File Report 95-270, 79 p.

Molzer, P.C., and Erslev, E.A., 1995, Oblique convergence during northeast-southwest Laramide compression along the east-west Owl Creek and Casper Mountain Arches, central Wyoming: American Association of Petroleum Geologists Bulletin, v. 79, no. 9, p. 1377-1394.

NRG Associates, 2005, [includes data current as of 2003], The significant oil and gas fields of the United States: Colorado Springs, Colo., NRG Associates, Inc.; database available from NRG Associates, Inc.; P.O. Box 1655, Colorado Springs, CO 80901, U.S.A.

Orr, W.L., 1986, Kerogen/asphaltene/sulfur relationships in sulfur-rich Monterey oils: Organic Geochemistry, v. 10, p. 499-516.
Palacas, J.G., Flores, R.M., Keighin, C.W., and Anders, D.E., 1994, Origin of oil in oil-saturated sandstones in the upper part of the Fort Union Formation (Paleocene), Castle Gardens and Signor Ridge areas, Wind River Basin, Wyoming, in Flores, R.M., Mehring, K.T., Jones, R.W., and Beck, T.L., eds., Organics and the Rockies Field Guide: Wyoming State Geological Survey, Public Information Circular No. 33, p. 83-97.

Paull, R.K. and Paull, R.A., 1986, Epilogue for the Permian in the western Cordillera-A retrospective view from the Triassic: University of Wyoming, Contributions to Geology, v. 24 , p. $243-252$.

Paull, R.K. and Paull, R.A., 1987, Lower Triassic rocks within and adjacent to the thrust belt of Wyoming, Idaho, and Utah, in Miller, W.R., ed., The Thrust Belt Revisited: Wyoming Geological Association 38th Field Conference Guidebook, p. 149-161.

Peterson, Fred, 1988, Pennsylvanian to Jurassic eolian transportation systems in the western United States: Sedimentary Geology, v. 56, p. 207-260.

Peterson, J.A., 1984, Permian stratigraphy, sedimentary facies, and petroleum geology, Wyoming and adjacent areas, in Goolsby, Jim, and Morton, Doug, eds., The Permian and Pennsylvanian Geology of Wyoming: Wyoming Geological Association 35th Annual Field Conference Guidebook, p. 25-64.

Picard, M.D., 1993, The early Mesozoic history of Wyoming, in Snoke, A.W., Steidtmann, J.R., and Roberts, S.M., eds., Geology of Wyoming: The Geological Survey of Wyoming Memoir No. 5, p. 211-248.

Piper, D.Z., and Link, P.K., 2002, An upwelling model for the Phosphoria sea-A Permian, ocean-margin sea in the northwest United States: American Association of Petroleum Geologists Bulletin, v. 86, no. 7, p. 1217-1235.

Roberts, L.N.R., Lewan, M.D., and Finn, T.M., 2004, Timing of oil and gas generation of petroleum systems in the southwestern Wyoming province: Mountain Geologist, v. 41, no. 3, p. 87-118.

Sando, W.J., Mackenzie, Gordon, Jr., and Dutro, J.T., Jr., 1975, Stratigraphy and geologic history of the Amsden Formation (Mississippian and Pennsylvanian) of Wyoming: U.S. Geological Survey Professional Paper 848-A, 83 p.

Sharkey, H.R., 1946, Geology and oil possibilities of the Sage Creek Dome, Fremont County, Wyoming: U.S. Geological Survey Oil and Gas Investigations Preliminary Map 53, scale 1:31,680.

Sheldon, R.P., 1967, Long-distance migration of oil in Wyoming: Mountain Geologist, v. 4, no. 2, p. 53-65. 
Silliman, J.E., Li, Maowen, Yao, Huangxin, and Hwang, Rong, 2002, Molecular distributions and geochemical implications of pyrrolic nitrogen compounds in the Permian Phosphoria Formation derived oils of Wyoming: Organic Geochemistry, v. 33, p. 527-544.

Simmons, S.P., and Scholle, P.A., 1990, Late Paleozoic uplift and sedimentation, northeast Bighorn Basin, Wyoming, in Specht, R.W., ed., Wyoming Sedimentation and Tectonics: Wyoming Geological Association 41st Annual Field Conference Guidebook, p. 39-55.

Sonnenfeld, M.D., 1996, Sequence evolution and hierarchy within the Lower Mississippian Madison Limestone of Wyoming, in Longman, M.W., and Sonnenfeld, M.D., eds., Paleozoic Systems of the Rocky Mountain Region, Rocky Mountain Section, SEPM, p. 165-192.

Stone, D.S., 1967, Theory of Paleozoic oil and gas accumulation in Big Horn Basin, Wyoming: American Association of Petroleum Geologists Bulletin, v. 51, no. 10, p. 2056-2114.

Stone, D.S., 2002, Morphology of the Casper Mountain uplift and related, subsidiary structures, central Wyoming: Implications for Laramide kinematics, dynamics, and crustal inheritance: American Association of Petroleum Geologists Bulletin, v. 86, no. 8, p. 1417-1440.
Tohill, Bruce, and Picard, M.D., 1966, Stratigraphy and petrology of Crow Mountain Sandstone Member (Triassic), Chugwater Formation, northwestern Wyoming: American Association of Petroleum Geologists Bulletin, v. 50, no. 12, p. 2547-2565.

Vredenburgh, L.D. and Cheney, E.S., 1971, Sulfur and carbon isotopic investigation of petroleum, Wind River Basin, Wyoming: American Association of Petroleum Geologists Bulletin, v. 55, no. 11, p. 1954-1975.

Westphal, Hildegard, Eberli, G.P., Smith, L.B., Grammer, G.M., and Kislak, Jason, 2004, Reservoir characterization of the Mississippian Madison Formation, Wind River Basin, Wyoming: American Association of Petroleum Geologists Bulletin, v. 88, no. 4, p. 405-432.

Whalen, M.T., 1996, Facies architecture of the Permian Park City Formation, Utah and Wyoming-Implications for paleogeography and oceanographic setting of western Pangea in Longman, M.W., and Sonnenfeld, M.D., eds., Paleozoic Systems of the Rocky Mountain Region, Rocky Mountain Section, SEPM, p. 355-378.

Wyoming Geological Association, 1989, Wyoming Oil and Gas Fields Bighorn and Wind River Basins: Wyoming Geological Association Symposium, 555 p.

Wyoming Oil and Gas Conservation Commission (WOGCC) accessed on (2005), at http://wogcc.state.wy.us/ 
Appendix A. Input data for the Tensleep-Park City Conventional Oil and Gas Assessment Unit (AU 50350101). Seventh Approximation Data Form for Conventional Assessment Units (NOGA, version 5, 06-30-01). Complete form including allocations is shown in Klett and Le (Chapter 2, this CD-ROM).

\section{SEVENTH APPROXIMATION \\ DATA FORM FOR CONVENTIONAL ASSESSMENT UNITS (Version 6, 9 April 2003)}

\begin{tabular}{|c|c|c|c|}
\hline & IDENTIFICATION INFORMATION & & \multirow[b]{2}{*}{$9 / 21 / 2005$} \\
\hline Assessment Geologist: & M.A. Kirschbaum & \multirow{7}{*}{$\begin{array}{l}\text { Date: } \\
\text { Number: } \\
\text { Number: } \\
\text { Number: } \\
\text { Number: } \\
\text { ion (1989) }\end{array}$} & \\
\hline Region: & North America & & 5 \\
\hline Province: & Wind River Basin & & 5035 \\
\hline Total Petroleum System: & Phosphoria & & 503501 \\
\hline Assessment Unit: & Tensleep-Park City Conventional Oil and Gas & & 50350101 \\
\hline Based on Data as of: & IHS Energy Group(2005), Wyoming Geological Associat & & \\
\hline Notes from Assessor: & NRG Associates (2005, data current through 2003) & & \\
\hline
\end{tabular}

\section{CHARACTERISTICS OF ASSESSMENT UNIT}

Oil ( $<20,000 \mathrm{cfg} / \mathrm{bo}$ overall) or Gas $(\geq 20,000 \mathrm{cfg} / \mathrm{bo}$ overall): _ _ Oil

What is the minimum accumulation size? $\quad 0.5$ mmboe grown

(the smallest accumulation that has potential to be added to reserves)

No. of discovered accumulations exceeding minimum size:

Established (>13 accums.)

X Frontier (1-13 accums.)

Oil: $18 \quad$ Gas:

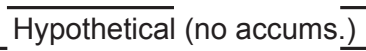

Median size (grown) of discovered oil accumulations (mmbo):

1 st 3 rd 14.4

Median size (grown) of discovered gas accumulations (bcfg):

1st 3rd

2nd 3rd $\quad$ 61.3 3rd 3rd

3.1

2nd 3rd

3rd 3rd

Assessment-Unit Probabilities:

Attribute

Probability of occurrence (0-1.0)

1. CHARGE: Adequate petroleum charge for an undiscovered accum. $\geq$ minimum size:

2. ROCKS: Adequate reservoirs, traps, and seals for an undiscovered accum. $\geq$ minimum size:

3. TIMING OF GEOLOGIC EVENTS: Favorable timing for an undiscovered accum. $\geq$ minimum siz

$\begin{array}{r}1.0 \\ \hline 1.0 \\ \hline 1.0 \\ \hline\end{array}$

Assessment-Unit GEOLOGIC Probability (Product of 1, 2, and 3):

1.0

\section{UNDISCOVERED ACCUMULATIONS}

No. of Undiscovered Accumulations: How many undiscovered accums. exist that are $\geq$ min. size?:

(uncertainty of fixed but unknown values)

Oil Accumulations:

Gas Accumulations:

$\underset{\operatorname{minimum}(>0)}{\operatorname{minimum}(>0)}$

mode

mode

5

maximum maximum 15 40

Sizes of Undiscovered Accumulations: What are the sizes (grown) of the above accums?:

(variations in the sizes of undiscovered accumulations)

Oil in Oil Accumulations (mmbo):

Gas in Gas Accumulations (bcfg): minimum minimum median median maximum maximum

1.5

$\frac{50}{300}$


Appendix A. Input data for the Tensleep-Park City Conventional Oil and Gas Assessment Unit (AU 50350101). Seventh Approximation Data Form for Conventional Assessment Units (NOGA, version 5, 06-30-01). Complete form including allocations is shown in Klett and Le (Chapter 2, this CD-ROM).-Continued

Assessment Unit (name, no.)

Tensleep-Park City, 50350101

AVERAGE RATIOS FOR UNDISCOVERED ACCUMS., TO ASSESS COPRODUCTS (uncertainty of fixed but unknown values)

Oil Accumulations:

Gas/oil ratio (cfg/bo)

NGL/gas ratio (bngl/mmcfg)

minimum

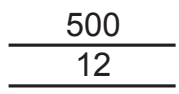

Gas Accumulations:

Liquids/gas ratio (bliq/mmcfg)

Oil/gas ratio (bo/mmcfg)

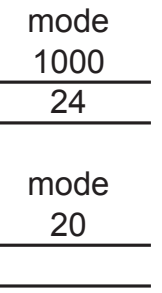

maximum 1500

36

maximum 30

\section{SELECTED ANCILLARY DATA FOR UNDISCOVERED ACCUMULATIONS}

(variations in the properties of undiscovered accumulations)

Oil Accumulations:

API gravity (degrees)

Sulfur content of oil (\%)

Depth $(\mathrm{m})$ of water (if applicable)

Drilling Depth (m)

Gas Accumulations:

Inert gas content (\%)

$\mathrm{CO}_{2}$ content (\%)

Hydrogen-sulfide content (\%)

Depth (m) of water (if applicable)

Drilling Depth (m) minimum

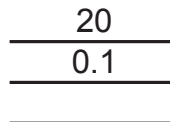

minimum

1000

F75

1866

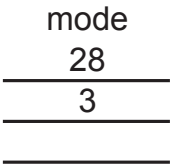

mode

2000

F25

2775

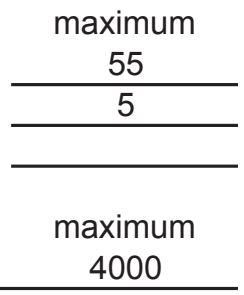

minimum

\begin{tabular}{c}
0 \\
\hline 0 \\
\hline 0 \\
\hline
\end{tabular}

mode

\begin{tabular}{c}
0.3 \\
\hline 0.5 \\
\hline 0.3 \\
\hline
\end{tabular}

minimum

F75

mode

3000

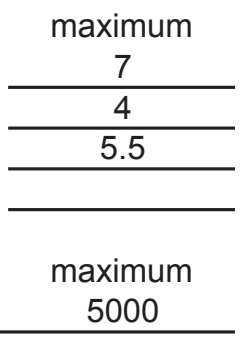




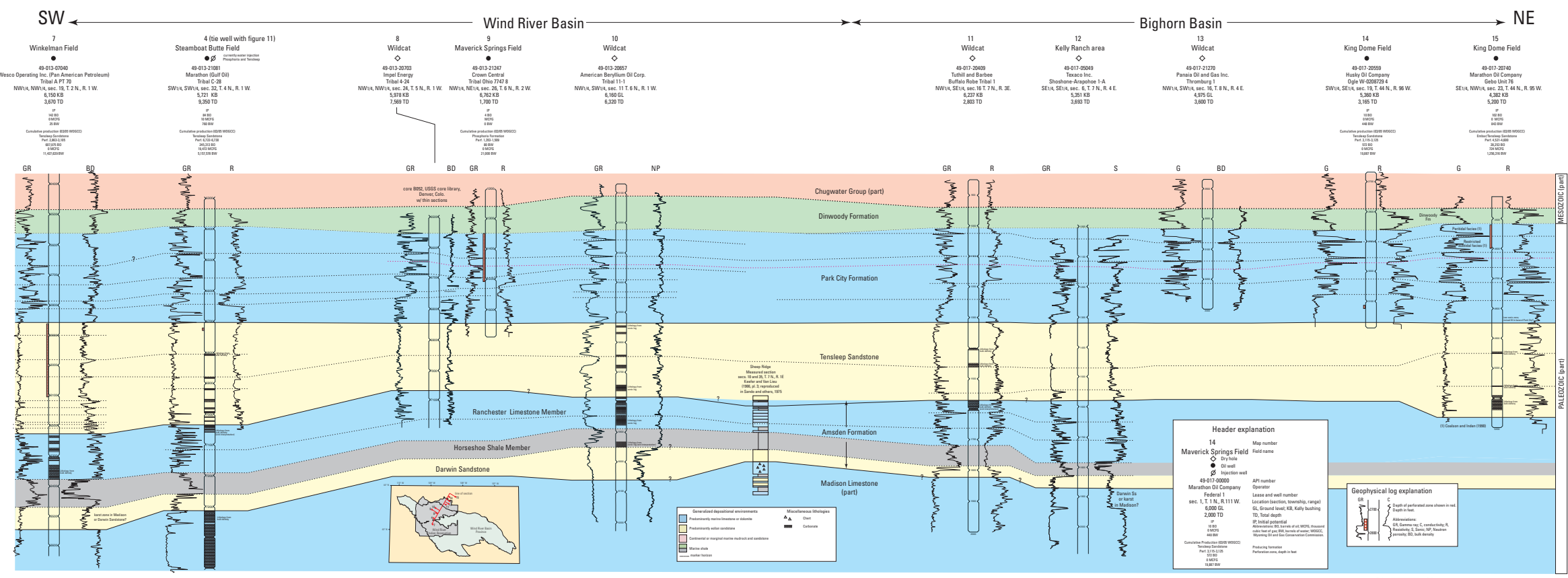

WLEOZIC AND LOWER MESOZOIC ROCKS IN THE WIND RIVER BASIN AND THE SOUTHERN BIGHORN BASIN Mark A. Kirschbaum, Paul Gy. Lillis, and Laura N.R. Roberts

Plate 1. Stratigraphic cross section showing uppermost Paleozoic and lowermost Mesozoic rocks in the Wind River Basin and the southern Bighorn Basin. Wells are projected into a southwest to northeast line of section. (Double click on image to link to full-size version for printing).

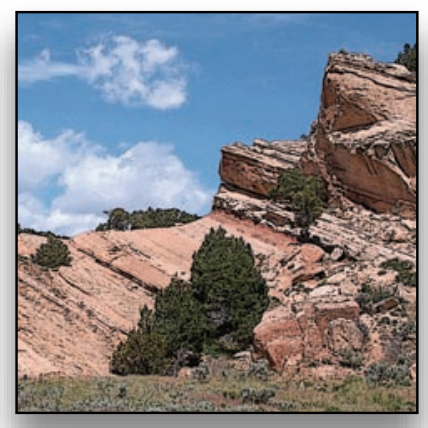

